\title{
Variability of key biological parameters of round sardinella Sardinella aurita and the effects of environmental changes
}

\author{
Baldé Bocar Sabaly 1, 2, 3, 4, , Sow Fambaye N. ${ }^{1}$, Ba Kamarel 1, 4, Ekau Werner ${ }^{2}$, Brehmer Patrice 1, 3 , \\ Kantoussan Justin ${ }^{5}$, Fall Massal ${ }^{1}$, Diouf Malick ${ }^{4}$
}

1 ISRA, CRODT, PRH, Dakar, Senegal.

2 Leibniz Ctr Trop Marine Ecol ZMT, Dept Ecol, Bremen, Germany.

3 Ifremer, Inst Rech Dev France IRD, UMR Lemar, CNRS,UBO,IRD, Dakar, Senegal.

4 Univ Cheikh Anta Diop, IUPA, UCAD II, Dakar, Senegal.

${ }^{5}$ Univ Gaston Berger, Unite Format \& Rech Sci Agronom Aquaculture \& Tec, St Louis, Senegal.

* Corresponding author : Bocar Sabaly Baldé, email address : bocarbalde2005@hotmail.com

\begin{abstract}
:
We examined growth rates and reproductive characteristics of Sardinella aurita off Senegal and other coastal areas over a 20 year period (1995-2014) to determine how they relate to variations in environmental characteristics of coastal waters. Based on fish length-frequency data and a coastal upwelling index, we found that $\mathrm{S}$. aurita recruitment tends to occur during the periods of most intensive upwelling (March-April off Senegal). Peak reproduction corresponds to periods of low sea-surface temperature (in February or March). The sex ratio was remarkably consistent during the 30 year study period and so was not affected by environmental changes. We hypothesise that $S$. aurita takes advantage of the higher zooplankton productivity that occurs in coastal waters when upwelling brings nutrient-rich water to the surface (i.e., it increases its growth rate and accumulates energy reserves for spawning). Growth performance appears to be strongly dependent on environmental conditions. The timing of spawning seems to occur when food (zooplankton) is most available for supplying the energy requirements needed by adults for spawning and early development of larvae. Environmental changes seem to have a significant effect on $\mathrm{S}$. aurita growth and reproduction, which endorses their high phenotypic plasticity.
\end{abstract}

Keywords : data poor fisheries, environmental variability, size structure, small pelagic, spawning period, west Africa 
The Canary Current off the West Africa coast initiates an upwelling zone that modifies the trophic structure of coastal ecosystems profoundly (Auger et al., 2016). The coastal upwelling region from $10^{\circ} \mathrm{N}$ to $35^{\circ} \mathrm{N}$ has been identified as one of many large marine ecosystems ("LMEs") of the world, with the southern part of this LME represented by the Senegal-Mauritanian upwelling system (Auger et al., 2016). In the more southern portion of this system off Senegal (between $12^{\circ} \mathrm{N}$ and $17^{\circ} \mathrm{N}$, upwelling occurs only during the winter-spring period. This upwelling is a response to the southern extension of the trade wind, which is defined by the position of the Intertropical Convergence Zone (Auger et al., 2016). The wind-forced upwelling of deep, nutrient-rich water is responsible for high primary productivity (of phytoplankton) in coastal waters, which provides the energy (food) for higher trophic levels. In the Senegal-Mauritanian region $\left(10^{\circ}-19^{\circ} \mathrm{N}\right)$, the geographic expansion of offshore phytoplankton production that occurs during winter and spring is followed by an abrupt decline in summer production (Auger et al., 2016). Bakun (1990) hypothesized that climate change may lead to an intensification of coastal upwelling in response to increasing favourable upwelling wind, and Barton et al. (2013) has predicted there is an increase in SST in general. In either case, changes in the upwelling intensity of the SenegalMauritanian system will influence the abundance of small pelagic fish, including Sardinella aurita (round Sardinella) and Sardinella maderensis (flat Sardinella) (Thiaw et al., 2017; Diankha et al., 2018). Thiaw et al. (2017) and Diankha et al. (2018) report that abundance and recruitment success of S. aurita are associated with distinct ranges of sea surface temperature, upwelling intensity, wind-induced turbulence, concentration of chlorophyll-a and north Atlantic oscillation index in Senegal.

The species S. aurita inhabits tropical and subtropical regions of the eastern Atlantic Ocean and occurs in high concentrations along the west coast of Africa in three main areas (Roy et al., 1989): between southern Morocco (Western Sahara) and Guinea $\left(10^{\circ}-26^{\circ} \mathrm{N}\right)$, between Ivory Coast and Ghana $\left(7^{\circ}-5^{\circ} \mathrm{N}\right)$ and further south between Gabon and southern Angola ( $0^{\circ}-18^{\circ}$ S) (Froese \& Pauly, 2016). S. aurita also occurs in the western Atlantic Ocean from Cape Cod (USA) to Argentina, including the Caribbean, West Indies, and Gulf of Mexico (Felder, 2009). It also inhabits the Mediterranean Sea (Boltachev \& Karpova, 2014). In all regions, the species preferentially inhabits continental shelves where it prefers saline (between $34 \mathrm{ppt}$ and $36.5 \mathrm{ppt}$ ), and warm sea temperatures (between $17^{\circ} \mathrm{C}$ and $30^{\circ} \mathrm{C}$ ) (Boëly, 1979). In Senegal, massive reproduction events occur south of the Cap-Vert peninsula (Dakar) to the delta of Saloum at the border with The Gambia (Conand, 1977; Boëly, 
1982). In terms of exploitation, S. aurita has already been intensively exploited by artisanal fleets in Senegal

60 (Thiao, 2009) and in Mauritania by foreign fishing fleets under fisheries agreements (e.g. Union European and

61 Russian Federation) and Morocco with a small artisanal fleet fishing near the coast (Isselmou \& Baye, 2009). Due

62 to the increasing demand for S. aurita for human consumption, the fishing effort of artisanal fleets in Senegal and

63 Mauritania has steadily increased in recent years.

64 Growth characteristics and breeding season of $S$. aurita populations vary among areas. For example, in the eastern 65 Atlantic (e.g., off Senegal), S. aurita possesses an asymptotic length of $36.5 \mathrm{~cm}$ total length (TL) (Boëly et al., 66 1982) and a breeding season that extends from February to May and from October to November (Boëly, 1982). In 67 western Atlantic Ocean (off Venezuela), the species possesses an asymptotic length of $32.6 \mathrm{~cm}$ (TL) and a 68 breeding period from January to March and from October to December (Gassman et al., 2008). In the 69 Mediterranean (off Greece), S. aurita reaches an asymptotic length of $21.4 \mathrm{~cm}$ (TL) (Tsikliras et al., 2005) and a 70 rather limited breeding period between May and June (Tsikliras \& Antonopoulou, 2006). Biological 71 characteristics of $S$. aurita, such as growth and reproduction, have been shown to be strongly influenced by 72 environmental conditions (e.g., upwelling intensity and sea surface temperature) in both the Mediterranean 73 (Tsikliras et al., 2005; Tsikliras \& Antonopoulou, 2006) and the West Atlantic (Fréon et al. 1997). Such findings 74 suggest that growth and reproductive periods of $S$. aurita in the eastern Atlantic (off Senegal) might also be 75 influenced by upwelling intensity and sea surface temperature.

76 To determine how environmental conditions might be affecting $S$. aurita populations and their biology, we 77 analysed landing data available for coastal Senegal from 1995 to 2014. The data collections included reproductive 78 condition (age of sexual maturity, length-frequency distributions, and condition factor) and growth parameters. 79 The results of this study were compared and discussed in relation to relevant past studies in various north tropical 80 Atlantic (Eastern and Western) and Mediterranean Sea areas. 


\section{MATERIAL AND METHODS}

\subsection{Biological data}

Data on the growth of $S$. aurita were obtained from fish that landed at the seven main artisanal fishing harbours along the Senegal coast from July 2013 to June 2014 (Fig. 1). Three harbours (Kayar, Saint-Louis and Yoff) are located in the northern part of the coast (from $16^{\circ} 04^{\prime} \mathrm{N}$ to $14^{\circ} 36^{\prime} \mathrm{N}$ ) where the continental shelf is narrow. The other harbours (Hann, Mbour, Joal and Kafountine) are located along the southern coast (from $14^{\circ} 36^{\prime} \mathrm{N}$ to $13^{\circ}$ $36^{\prime} \mathrm{N}$ and from $13^{\circ} 04^{\prime} \mathrm{N}$ to $12^{\circ} 20^{\prime} \mathrm{N}$ ) where the continental shelf is wider than the northern part. Length frequency data were collected randomly at about 5 days per week. This study sampled only specimens caught using purse seine nets to have the same fishing gear selectivity for monthly comparisons of the length distribution.

Total length ( $\mathrm{TL}$ in $\mathrm{cm}$ ) of fish sampled ( $\mathrm{n}=32346$ individuals) was measured to the nearest $1 \mathrm{~mm}$, while the body weight (W) was determined to the nearest $0.01 \mathrm{~g}$. Sampled individuals were grouped into 1-cm-interval size classes to calculate size-frequency distributions and to estimate growth parameters.

Length-weight relationship (Le Cren, 1951) was determined for both males and females:

$$
W=a \times T L^{b}
$$

Where $\mathrm{W}$ is the weight and TL is the Total Length, and $\mathrm{a}$ and $\mathrm{b}$ allometric coefficients.

The data we used for our study of $S$. aurita reproduction were collected by other surveys of the artisanal fisheries along the southern Senegal coast from 1995 to 2011, including surveys by the Fishery Research Vessel (FRV) Fridtjof Nansen (Charouki et al., 2011) and by the Centre de Recherches Océanographiques de Dakar-Thiaroye (CRODT in French) covering Senegal (i.e., Senegal Fisheries Research Centre). These fish surveys were conducted regularly from November through December with a few surveys covering the June-to-July period. In Senegal, massive reproduction events occur south of the Cap-Vert peninsula (Dakar) to the delta of Saloum at the border with The Gambia (Conand, 1977; Boëly, 1982) (Fig.1). A total of 4397 fish samples were recorded during the surveys (Table I). The FRV Fridtjof Nansen stopped collecting samples in 2006, at the end of its research project, but technicians involved in the surveys from the CRODT continued to collect seasonal samples until 2011. Weight of gonads $(0.1 \mathrm{~g})$ and sex were determined for 4397 fish. Stages of maturity were determined macroscopically using the Fontana (1969) maturity scale (Table II). 
The von Bertalanffy (1938) growth parameters [coefficient of growth rate $(\mathrm{K})$, asymptotic length $\left(\mathrm{L}_{\infty}\right)$, time "t" when the fish length is zero $\left(\mathrm{t}_{0}\right)$ ] were estimated from monthly length-frequency data using the 'TropFishR' (Tropical Fisheries Analysis with R) package (Mildenberger et al., 2017), while natural mortality was estimated using the McQuinn et al. (1990) method:

$$
M=3 / t_{\max }
$$

Where $t_{\max }$ is the longevity of the species that is by definition the age corresponding to the size average maximum $\left(\mathrm{L}_{\max }=95 \% \mathrm{~L}_{\infty}\right)$ that a fish can reach and estimated by the following equation of Pauly (1983):

$$
t_{\max }=(3 / K)+t_{0}
$$

The growth performance index $\left(\varphi^{\prime}\right)$ was used to compare growth rates among $S$. aurita and evaluate growth performance potential under different environmental constraints (Tsikliras et al., 2005). Growth parameters of $S$. aurita from the different Mediterranean, Central Atlantic stocks were used to construct an auximetric double logarithmic plot of an individual's coefficient of growth rate $(\mathrm{K})$ against an estimate of its asymptotic length $\left(\mathrm{L}_{\infty}\right)$. The spawning period of $S$. aurita was determined using two approaches: (1) a qualitative approach based on monitoring monthly fluctuations in the percentage of different stages of gonad development and (2) a quantitative approach based on the monthly change in the gonado-somatic index (GSI; in \%). GSI was calculated for each sampled individual based on Le Bec, (1983):

$$
G S I=\frac{W_{g}}{W_{e v}} \times 100
$$

Where $\mathrm{W}_{\mathrm{g}}$ is gonad weight and $\mathrm{W}_{\mathrm{ev}}$ is eviscerated fish weight.

We used the equation proposed by Le Cren (1951) to calculate each individual's condition factor (Kn):

$$
K n=\frac{W_{T}}{W_{t h}}
$$

$\mathrm{W}_{\mathrm{T}}$ : total individual fish weight and $\mathrm{W}_{\mathrm{th}}$ : the theoretical total weight calculated from Eq. 1. This relationship (Eq. 5) indicates that the bigger the fish, the better the environment. The study of this factor makes it possible to see which cycle, seasonal and annual, obeys weight gain of individuals.

Mean length at first sexual maturity $\left(\mathrm{L}_{50}\right.$; in $\mathrm{cm}$ ) was estimated using only fish collected during reproductive periods (February to June and October to November) (Boëly, 1982; Cury \& Fontana, 1988) from 1995 to 2011. A logistic function with an inflection point at $0.5\left(\mathrm{~L}_{50 \%}\right)$ was used to model the relationship between the percent of mature females ( $\mathrm{M} \geq$ Stage III) and total length TL. The following equation was used, where $b$ is a constant of the model:

$$
M=\frac{1}{1+e^{-b\left(T L_{t}-L_{50 \%}\right)}} \times 100
$$


137 For comparison with the results of this study, growth and reproductive parameters from various north tropical 138 Atlantic (Eastern and Western) and Mediterranean areas are shown in Appendix, as well as the data sources.

\subsection{Landing data}

The data set was total landing of S. aurita by the Senegal artisanal fishery from 1995 to 2014 by the type of fishing gear used (purse seine) and landing port (Kayar, Saint-Louis and Yoff, Hann, Mbour, Joal, and Kafountine). These data set was extracted from the CRODT database (Figure 1). The number of trips per fishing gear was recorded on a daily basis, whereas landing data were collected randomly at about 5 days per week. After sorting the data by port, gear type and period (fortnightly intervals), total landings per port were estimated by multiplying the mean number of fish landed for the sampled trips by the total number of fishing trips made (Chaboud et al., 2015). The landings were summed by month for each landing port (Chaboud et al., 2015). Growth (July 2013 to June 2014) and reproduction (1995 to 2011) data by size, sex, maturity stages and landing sites were extrapolated with landing data from 1995 to 2014 ..

\subsection{Environmental data}

We used local environmental indices [Coastal Upwelling Index (CUI) and coastal sea surface temperature (SST)] for the period from 1995 to 2011 to analyse the effect of the environmental conditions on seasonal and interannual variability of key biological parameters (mainly reproduction) of $S$. aurita. Both data sets were obtained from the Southern Senegal coast (Fig. 1). The SST $\left({ }^{\circ} \mathrm{C}\right)$ data (averaged on a monthly basis) were obtained from advanced, very-high-resolution radiometer (AVHRR) satellite images (5 km resolution) from Southern Senegal coast to the $200 \mathrm{~m}$ isobath, where upwelling-induced SST anomalies are generally maximal (Thiaw et al., 2017).

The CUI $\left(\mathrm{m}^{3} \mathrm{~s}^{-1} \mathrm{~m}^{-1}\right)$ was deduced from wind speed data obtained from the U.S. NOAA Environmental Research Division website (ERD, Upwelling and Environmental Index Products, http://www.pfeg.noaa.gov; Upwelling and Environmental Index Products, last visited: 20/11/2017). In order to calculate the CUI in the Southern Senegal, we used the method of Ekman's theory (Ekman, 1905) of the transportation of masses of surface water by wind in the north or north-east direction, coupled with the rotation of the earth:

$$
C U I=\frac{\tau}{\rho_{\omega} f}
$$


Where $\tau$ is the along shore component of wind stress within $270 \mathrm{~km}$ of the coastline (positive southward), $\rho$ is the seawater density $\left(1025 \mathrm{~kg} \mathrm{~m}^{-3}\right)$ and $\mathrm{f}$ is the Coriolis parameter $(=2 \Omega \sin (\theta)$, with $\Omega$ and $\theta$ equal to the Earth's angular velocity and latitude, respectively).

\subsection{Statistical analysis}

All fork length (FL) measurements were converted to total length (TL) according to the relationship (Sylla et al., 2016):

$$
F L(m m)=10.8264+0.8066 T L(m m) \quad<->T L=(F L-10.8264) / 0.8066
$$

All statistical analyses were performed using the "stats", "mgcv" and "Hmisc" R packages (De Mendiburu, 2014; Harrell Jr, 2017; Wood \& Wood, 2017), with a significance level of $\alpha<0.05$.

Condition factor $(\mathrm{Kn})$ was assessed over annual and interannual temporal scales to test whether environmental parameters affected S. aurita reproduction. The Generalized Additive Model (GAM) (Hastie \& Tibshirani, 1986; Diankha et al., 2018) was used: (i) to quantify the contribution of the environmental variables (CUI, SST); and (ii) to investigate ranges of each environmental variable associated with condition factor. This model does not require any prior assumption on the functional link between each variable and the condition factor. The explanatory variables included in the model were: SST, CUI. We used the smooth function "s", estimated from the data. This function is used to define smooth terms in the GAM model formulas. The function does not evaluate a smooth (spline), but exists only to help configure a model using spline-based smoothing (Wood \& Wood, 2017). Multicollinearity of explanatory variables was tested using the variance inflation factor (VIF) on SST, CUI (Tiedemann \& Brehmer, 2017). The variance inflation factors (VIFs) were calculated for all environmental variables to detect possible high dimensional collinearities (Zuur et al., 2010; Tiedemann \& Brehmer, 2017; Diankha et al., 2018). A VIF $<2$ for all tested explanatory variables was considered adequate (Zuur et al., 2010). Because recruitment was estimated by season [to focus on species biology (the seasonal influence on fecundity)] (Boëly, 1982), season was the temporal unit used to evaluate the effect of environmental variables. The seasonal and interannual means of these three variables were also computed.

$$
\text { Model }<-\operatorname{gam}(K n \sim s(C U I)+s(S S T), \text { data }=\text { Input data })
$$

The $\chi^{2}$-test was used to compare sex ratios and proportion of individual in each stage, which made it possible to determine whether the variables observed for the Petite côte and the Northern part of S. aurita were independent. The Petite côte (from $14^{\circ} 36^{\prime} \mathrm{N}$ to $13^{\circ} 36^{\prime} \mathrm{N}$ ) extends from the south of the peninsula of Cap Vert (Dakar) to the 

delta of Saloum at the border with The Gambia, and includes a $130 \mathrm{~km}$ long and $10 \mathrm{~km}$ wide continental shelf

191 (Fig. 1). We used analyses of variance (ANOVAs) to compare reproductive parameters between males and 192 females and the growth performance index $\left(\varphi^{\prime}\right)$ of different oceanic regions (Mediterranean, Western and Eastern 193 Central Atlantic), followed by Kruskal-Wallis tests. The growth performance index ( $\varphi$ ') was used to compare 194 growth rates and to assess the potential for growth under various environmental stresses.

\subsection{Ethics statement}

196 No specific authorization was required for any activities undertaken during this work at any of the sites visited. 197 The study was conducted in the waters of the Senegalese State. The activities carried out were in collaboration 198 with the Local Fishing Committee (CLP in French) and the local fishermen. Threatened or protected species have 199 not been involved in any part of the field studies.. No approval was required from the Institutional Animal Care 200 and Use Committee, and no field license was required during any part of the experiment. 


\section{RESULTS}

\subsection{Size spectra and length-weight relationships}

The length-frequency distributions between coastal areas (northern and southern part) showed that $S$. aurita off the northern part are larger (mode: $32 \pm 2 \mathrm{~cm}$ ) than fish caught off the southern coast (two modes: $13 \pm 1$ and $24 \pm$ $3 \mathrm{~cm}$ ) (Fig. 2). The size distribution of the southern population exhibited a higher peak at a smaller size $(24 \mathrm{~cm})$ relative to the northern individuals (peak at $32 \mathrm{~cm}$ ).

The relationship between the total weight and total length was allometric $[a=0.008 \pm 0.001 ; b=3.02 \pm 0.01$, and $r$ $=0.93(\mathrm{n}=4397)]$. Fig. 3 indicates fish growth in length to be faster than gaining weight when it is young and the older the fish the less the fish is growing in length but is gaining in weight. Only in a very short period, it seems that the fish is relatively seen gaining weight and length at the same rate.

\subsection{Temporal variability of condition factor and environmental parameters}

The condition factor $(\mathrm{Kn})$ varied seasonally $\left(X^{2}=22.01, \mathrm{df}=11, \mathrm{p}=0.001\right)$ with maximum values in May and September (Fig. 4a). The increase in Kn from February to May corresponds to a period of high upwelling intensity (CUI) and low sea surface temperature (SST) along the "Petite côte" (Fig.1) in March-April. Thereafter, Kn declined until August as the CUI declined. A maximum Kn in September was again followed by a decline in CUI and an accelerated decline in SST. The seasonal cycle of declining SST coincides with an increase in CUI because strong offshore, wind-induced upwelling in winter brings cold water to the surface. The relationship between $\mathrm{Kn}$ and CUI and SST showed wider amplitude on an annual basis than did seasonal variations ( 0.88 to 1.14, Fig. 4b). The condition factor for $S$. aurita remained fairly stable over the study 17 -year period, except for two peaks, one in 1998 (1.2) and the other in 2003 (1.1). Over the period 1995-2011, SST and CUI varied interannually. Mean sea surface temperatures increased in 1998, 2001, 2005, 2008 and 2010, but decreased in 1999 and 2009. The most striking feature during this period was the slight drop in the upwelling index in1997 at 0.84 $\mathrm{m}^{3} \mathrm{~s}^{-1} \mathrm{~m}^{-1}$. However, as a result of this slight weakening of the CUI, the CUI showed a rapid and considerable increase in 2004 and 2009. Although both condition factor and environmental phenomena varied seasonally, the variation in Kn was related to CUI (F-stat $=6.186 ; p=0.0143)$ and not for the SST $(\mathrm{F}$-stat $=3.238 ; \mathrm{p}=0.0745)$.

The model explains $5.19 \%$ of the observed variability with R-sq. $(\operatorname{adj})=0.03$. During the study period $(1995$ 2011), the condition factor reached its maximum at CUI $\approx 1 \mathrm{~m}^{3} \mathrm{~s}^{-1} \mathrm{~m}^{-1}$ in 1995, 2003 and 2006 (Fig. 5). 


\subsection{Growth parameters}

230 Based on the length frequency data, $\mathrm{L}_{\infty}, \mathrm{K}$ and $\varphi^{\prime}$ for July 2014 to June 2015 were estimated to be $35.4 \mathrm{~cm}, 0.26$ 231 year $^{-1}$ and 2.51 respectively. Sardinella aurita grows quickly during its first year, while subsequent growth rates decline gradually with age. No statistical differences between the growth performance index ( $\left.\varphi^{\prime}\right)$ of historical data collected off the Senegal coast and data collected from other areas of the Eastern Central Atlantic was found $($ ANOVA: $\mathrm{F}$ value $=2.371, \mathrm{p}=0.139) \quad($ Appendix, Table I). However, we did find a significant difference between $\varphi^{\prime}$ data from the Senegal coast and other regions (West Atlantic, East Atlantic, and Mediterranean) $($ ANOVA: $\mathrm{F}$ value $=10.81, \mathrm{p}=0.001)($ Appendix, Table I). The Eastern Central Atlantic and Western Central Atlantic did not differ statistically (Tukey: $\mathrm{df}=0.15, \mathrm{p}=0.171$ ), while the Eastern Central Atlantic and the Mediterranean differed significantly (Tukey: $\mathrm{df}=0.33, \mathrm{p}=0.001$ ). The growth parameters $\left(\mathrm{L}_{\infty}, \mathrm{K}\right.$ and $\left.\varphi^{\prime}\right)$ of $S$. aurita in the Eastern Central Atlantic were higher than Western Central Atlantic and Mediterranean Sea (Fig. 6) and decline over time (from 1932 to the present study), while in the West Atlantic, there was an increasing of $\mathrm{L}_{\infty}$. Asymptotic length $\left(\mathrm{L}_{\infty}\right)$ was lower in the Western Central Atlantic than in the Eastern Central Atlantic (Tukey: df $=0.15, \mathrm{p}=0.001$ ). Sardinella aurita inhabiting these two coastal systems (Eastern and Western Central Atlantic) are characterized by higher lifespans $\left(t_{\max }\right)$, higher maximum lengths $\left(\mathrm{L}_{\max }\right)$ and longer asymptotic lengths $\left(\mathrm{L}_{\infty}\right)$ than those inhabiting the Mediterranean (Tukey: $\mathrm{df}=0.15, \mathrm{p}=0.001$ ) (Appendix, Table I). However, growth parameters seem to have remained constant in the Mediterranean over the period examined (from 1932 to 2012; Fig. 6).

\subsection{Maturity}

Sex ratio (SR) for $S$. aurita was in balance with around $51 \%$ females. The cumulative frequency curve of individuals that had reached or passed maturity Stage 3 indicated that $50 \%\left(\mathrm{~L}_{50}\right)$ of males were mature at $24.8 \pm$ $1.0 \mathrm{~cm}$, while $50 \%$ of females were mature at $25.7 \pm 1.8 \mathrm{~cm}$. We found significant differences between maturity stages (proportions of fish in each stage) for the period investigated (1995-2011) (Table III). This sentence is linked with the results showed in the Fig. 7 and 8.

Two main reproductive periods were determined from our analysis of sexual maturity stages and GSI. For this study, the reproductive period was defined as the period between gonad maturation (Stage $\geq 3$ ) to spawning. The 
257 present in January, March, and April and from October to December after the first reproductive period. A second 258 reproductive period, with continuous spawning (more intense than during the first period), occurred from October 259 to the end of December.

260 The monthly record of sexual maturity stages showed that females in stage VI and VII were more abundant from 261 January to February and from July to December. The proportion of females at stages > IV peaked in January to 262 April, and September to December (Fig. 7a). Stage III females were mainly present in June. Stage V males were 263 present in February-March and from August to December. Stage III and IV males were found throughout the year 264 mostly from May to November (Fig. 7b).

265 Monthly changes in GSI followed sexual maturity Stages IV and V (Fig. 8). There were two spawning peaks in 266 April and October. In October, there was a higher presence of Stage IV and V individuals and higher GSI values 267 relative to September and November for males and females. A resting period between spawning occurred in June 268 and August. 


\subsection{Growth strategy of Sardinella aurita}

Three main size classes exist among $S$. aurita inhabiting Senegal coastal waters, suggesting that the adults mainly inhabit more northern coastal waters, while juveniles and young breeders $(<25 \mathrm{~cm})$ are concentrated off the southern coast. The highest concentration of juveniles and young breeders off the "Petite côte" of Senegal has been linked to a nursery area located there (Roy et al., 1989; Tiedemann \& Brehmer, 2017). Roy et al. (1989) assumed that the concentration of juveniles and young breeders in Senegal's southern coastal waters may be due to differential functioning, whereas the northern waters, northward the Cap Vert peninsula (Dakar), where physical properties differ significantly, i.e., mesoscale activity, Ekman coastal divergence and upwelling patterns (Ndoye et al., 2017), which play a role in system productivity and retention processes mean (e.g., larval retention). Indeed, the "Petite côte" of Senegal is characterised by high phytoplankton biomass (Auger et al., 2016) and high chlorophyll content during upwelling events (Auger et al., 2016), which are conditions optimal for providing a suitable nursery (Tiedemann \& Brehmer, 2017). Tiedemann \& Brehmer (2017) suggested that the retention of ichthyoplankton over the shelf was related to food availability, and is important for the reproduction of many pelagic species during the planktonic stages. Indeed, they are able to detect variations in temperature and can follow masses of water whose behavior or quality (nutritive, calorific) suits them (Chikhi, 1995). Thus, temperature and food availability is generally the most important condition for habitat selection.

Growth parameters $\left(\mathrm{L}_{\infty}, \mathrm{K}\right.$ and $\left.\varphi^{\prime}\right)$ for $S$. aurita in the Eastern Central Atlantic differ from patterns in the Mediterranean Sea, but no significant differences were found between the Eastern and Western Central Atlantic. Differences in S. aurita growth between the central Atlantic and Mediterranean may be related to differences in food abundance or environmental conditions (Wootton, 1998). The growth parameter and asymptotic length for a same short life species are higher in the most productive area (Fig. 6). The availability of food and temperature in Mediterranean is much lower than the Eastern Central Atlantic (Stergiou, 2000). Indeed, the instability of primary production and hydrographic conditions (Puerta et al., 2015) could make the Mediterranean less suitable for $S$. aurita populations. The complex mesoscale eddy complexes of the western Mediterranean resulting from the influx of Atlantic waters have different implications for feeding, transport and larval survival. This has important consequences for the productivity and functioning of the Mediterranean pelagic ecosystem (Puerta et al., 2015). According to Bakun (2013), some mid-scale vorticity features provide improved feeding and retention conditions 
for pelagic larvae. While in the Californian Current, a significant delay in the spring transition (Barth et al., 2007) might change the ecosystem, affecting primary production (Thomas \& Brickley, 2006), zooplankton (Mackas et al., 2006), and fish (Brodeur et al., 2018). For example, the growth of Atlantic herring Clupea harengus harengusis related in part to the temperature of summer water (Anthony \& Fogarty, 1985) while in Pacific herring Clupea harengus pallasi, Haist and Stocker (1985) found that SST of $12^{\circ}-13^{\circ} \mathrm{C}$ was optimal for juvenile growth. In the Eastern Central Atlantic, the seasonal variability of wind forcing is the main driver of seasonal variability in surface chlorophyll (Auger et al., 2016) and affects the distribution and abundance of fish populations, and their associated fisheries, over a large range of timescales (Thiaw et al., 2017). The environmental processes responsible for changes in growth rates between different regions are not always clearly identified, but in most of the examples given, they seem to be related to temperature and abundance of food.

In addition to environmental factors, high rates of fishing mortality can alter population structure and growth rates. For example, in the Mediterranean Sea (Greece), it increased from $32 \mathrm{~cm}$ in 1952 (Ananiades, 1952) to 21 $\mathrm{cm}$ in 2005 (Tsikliras et al., 2005) $(\Delta=-11 \mathrm{~cm})$. On the contrary, there is an increase in asymptotic length in the western central Atlantic of Venezuela (Mendoza et al., 1994) estimated at $26 \mathrm{~cm}$ (in 1994) and recently, the study of Barrios et al. (Barrios et al., 2010) showed a slight increase in asymptotic length to $27 \mathrm{~cm}(\Delta=+1 \mathrm{~cm})$. In Atlantic Eastern Central, we observe a decrease of asymptotic length $\mathrm{L}_{\infty}$ of $S$. aurita, particularly in Senegal, from $42 \mathrm{~cm}$ in 1950 (Postel, 1955) to $35.4 \mathrm{~cm}$ in this study (2013-2014) $(\Delta=-7 \mathrm{~cm})$. In Greece, the commercial exploitation of S. aurita has steadily increased since the early 1990's (National Statistical Service of Hellas, 19902002) due to a high fish market demand drive by the canning industry as bait for the profitable tuna and swordfish fisheries. Total landings increased from $69 \mathrm{t}$ in 1990 to $2733 \mathrm{t}$ in 2002 (Tsikliras, 2004). At the same time, in the west-central Atlantic area, S. aurita has not yet reached the state of overexploitation. In addition, a drastic reduction in catches was reported in 2009 (WECAFC, 2014). Sardinella aurita has been overexploited off West Africa for a decade (FAO, 2016) and Thiaw et al. (2017) assumed that increased fishing presence could have a strong influence on the decline in $S$. aurita growth in Senegal. As concluding remark, the environmental characteristics and the level of fishing pressure on a small pelagic fish species had a balanced impact on their growth parameters and asymptotic length at least for $S$. aurita, and thus should be considered as phenotypic parameters. 


\subsection{Reproductive strategy of Sardinella aurita}

A sex ratio biased slightly toward females $(51.1 \%)$ agrees with results of several authors studying the $S$. aurita population off Senegal (Conand, 1977; Boëly, 1982), Mauritania (Wague \& Mbodj, 2002) and the Mediterranean. Boëly (1979) noted there was a slight predominance of females (55\%) among younger and older individuals off the Senegal coast. This slight difference in sex ratio could be attributed to differences in reproductive growth [(more females are produced) (Boëly, 1982)], differential mortality or differences in the energy cost of reproduction between sexes (Tsikliras \& Antonopoulou, 2006). Size at first sexual maturity for males and females was 24.8 and $25.7 \mathrm{~cm}$, respectively in our present study. Conand (1977), Boëly (1982), and Fréon (1988) found smaller size at first sexual maturity than present study while Goudiaby et al. (2008) and Samba (2011) found larger sizes at first sexual maturity than present study (see Appendix, Table II) for both males and females. According to Boëly (1982), size of $S$. aurita at first sexual maturity may vary from one year to another or within the same year. In the Mediterranean, the size at first maturity of $S$. aurita varies from $15 \mathrm{~cm}$ to $16.8 \mathrm{~cm}$ for females and from $14 \mathrm{~cm}$ to $15.8 \mathrm{~cm}$ for males, whereas in the Western Central Atlantic (where most studies have focused on females), the size at first sexual maturity ranged from $18 \mathrm{~cm}$ to $20 \mathrm{~cm}$. We can therefore assume that the size at first sexual maturity for S. aurita also varies throughout its distribution. Size at first maturity depends on environmental and genetic factors (Wootton, 1998), but may also be influenced by other factors, such as longterm fishing pressure (Thiaw et al., 2017). Adaptive phenotypic plasticity is often the only way for populations to react quickly to environmental change and thus ensure their survival. A change in size at first maturity for an $S$. aurita population is probably one of the best indicators of its response to changes and/or stress in its environment. The length-weight relationship parameters calculated for $S$. aurita caught in the Eastern Central Atlantic (Mauritania and Senegal) are similar in values to those calculated for fish in the Western Central Atlantic (off Venezuela). However, lower values have been calculated for fish caught in the Mediterranean (Koutrakis \& Tsikliras, 2003). Many factors (e.g., morphology, proportion of fatty acids, sex, sexual stage, egg density, condition of the digestive tract, etc.) can lead to fluctuations in the weight of an individual fish (Wootton, 1998). Weight is determined by the condition factor $(\mathrm{Kn})$. Variations in $\mathrm{Kn}$ suggest that males and females adopt a similar energy intake strategy during gonad maturation and spawning in that $\mathrm{Kn}$ reaches its maximum value the month before the beginning of spawning (May or September). According to Boëly (1982) and Fréon (1988), the weight of $S$. aurita seems to be intimately related to upwelling intensity and agrees with the results obtained in present study.. 
Studies of $S$. aurita populations sampled off the coast of Senegal have shown that sexual activity occurs over most of the year and that number and magnitude of spawning peaks change from year to year and from one area to another (see Appendix, Table II). The spawning pattern we found in our study corresponds to the patterns identified by Cury and Fontana (1988) in Senegal. However, the pattern differed from those identified by Conand (1977), Boëly (1982), Goudiaby et al (2008) and Samba (2011) for Senegal and by Wague and Bodj (2002) for Mauritania. Spawning seems to be correlate with periods of high zooplankton abundance. In West Africa, breeding strategies are associated with local environmental conditions (Fréon, 1988; Roy et al., 1989). In places where spawning occurs in twice annually, $S$. aurita is better able to exploit its environment and maintain its population. A single peak of reproduction over a two-month (Tsikliras \& Antonopoulou, 2006), three-month (Gaamour et al., 2001), or four-month period (Ananiades, 1952) occurs in the Mediterranean, whereas a more extended breeding season occurs in the Western Central Atlantic (October to April), which supports our results for those coastal areas. We observed in present study that peak spawning corresponds to periods of low sea surface temperature (February or March, depending on the year). This may be due to temperature having a direct effect on the flow of energy through an ecosystem and population dynamics (Thiaw et al., 2017; Diankha et al., 2018). Species-specific differences in fish tolerance to abiotic factors (e.g., temperature, food availability, and other abiotic factors) show species-specific changes in population fecundity. In patients, embryonic stage duration and larval survival are treated with physical processes, at water temperature and food availability, which affect recruitment in upwelling systems (Tiedemann \& Brehmer, 2017). Repetitive breeding tends to have a longer spawning season than recruited spawners; thus increasing the likelihood that their offspring will encounter favourable environmental conditions for growth and survival. The many environments studied, it is generally accepted that changes in SST alter ecological stability. Ben-Tuvia (1960) found a positive relationship between the SST in March (pre-spawning period) and the strength of the year-round sardinella age classes in Israel (Mediterranean). In Southern California (Eastern Central Atlantic), warm temperatures allow larval development and successful breeding of sardines (MacCall, 2009). Thus, water temperatures and food availability can affect abundance (Thiaw et al., 2017), recruitment (Diankha et al., 2018), stages of egg and larvae (Tiedemann \& Brehmer, 2017), distribution (Sarré et al., 2018) and productivity (Auger et al., 2016) pelagic fish. Any modification at the level of temperature and upwelling might cause a mismatch between $S$. aurita reproduction and occurrence of their food and other organisms, leading to recruitment failures. 
382 Sardinella aurita adopts a specific growth and reproductive strategy that is a reaction to specific environmental 383 cues. We observed significant differences in the Eastern Atlantic Ocean vs the Mediterranean Sea. The primary 384 spawning period for S. aurita occurs in times of high zooplankton abundance (during upwelling) and in places 385 that is generally the most favourable for early life stage development. This strategy allows $S$. aurita to adapt its 386 abundance to fluctuations in food availability. Surprisingly, even under the effect of multiple stressors (mainly 387 environmental changes), the size at spawning for S. aurita does not vary in the Canary Current LME. Such result 388 should be considered in management purposes particularly in the context of climate change, and suggest that such 389 parameters must be regularly updated for accurate fisheries management. 


\section{ACKNOWLEDGEMENTS}

391 We would like to thank the editor and two anonymous reviewers for their insightful comments on the manuscript 392 and their very useful suggestions, which significantly improved its quality. Data analysis was done inside the 393 AWA project funded by IRD and the BMBF (grant 01DG12073E), www.awa.ird.fr (SRFC: Sub Regional 394 Fisheries Commission), the Preface project funded by the European Commission's Seventh Framework Program 395 (2007-2013) under Grant Agreement number 603521, https://preface.b.uib.no/ and the DAAD program under 396 Grant Agreement number 57314022. The data for this study were collected through the CRODT (Senegal) 397 fisheries information system from 1996-2013 and the ComFish project from 2014-2015 (funded by USAID). We 398 are thankful to USAID Comfish project for allowing the use of their database and all CRODT technicians for 399 their professionalism during the data collection on the field all the year around. 


\section{AUTHOR CONTRIBUTIONS}

401 Conceptualization: BSB PB WE.

402 Data curation: BSB FNS.

403 Formal analysis: BSB KB JK.

404 Methodology: BSB KB.

405 Project administration: BSB PB.

406 Resources: FNS.

407 Software: BSB KB.

408 Validation: PB, WE.

409 Supervision: MF MD.

410 Visualization: BSB.

411 Writing - original draft: BSB.

412 Writing - review \& editing: PB WE JK KB.

413 All authors contributed critically to the drafts and gave final approval for publication. 


\section{COMPETING INTERESTS}

415 The authors have declared that no competing interests exist. 
417 Ananiades, C. (1952) Quelques Considérations Sur L'allache Biométriques (Sardinella aurita CV). Praktika 418 Hellenic Hydrobiological Institute 5, 5-45.

419 Anthony, V. C. \& Fogarty, M. J. (1985) Environmental Effects on Recruitment, Growth, and Vulnerability of Aquatic Sciences 42, s158-s173.

Auger, P.-A., Gorgues, T., Machu, E., Aumont, O. \& Brehmer, P. (2016) What Drives the Spatial Variability of Primary Productivity and Matter Fluxes in the North-West African Upwelling System? A Modelling Approach and Box Analysis. Biogeosciences 13, 6419-6440.

Bakun, A. (1990) Global Climate Change and Intensification of Coastal Ocean Upwelling. Science 247, 198-201. Bakun, A. (2013) Ocean Eddies, Predator Pits and Bluefin Tuna: Implications of an Inferred 'low Risk-limited Payoff'reproductive Scheme of a (Former) Archetypical Top Predator. Fish and Fisheries 14, 424-438. Barrios, A., Guzmán, R., Mendoza, J., Gómez, G. \& Vizcaino, G. (2010) Parámetros de Crecimiento Y Mortalidad Total de La Sardina Sardinella aurita (Valenciennes, 1810) En El Nororiente Venezolano Durante El Período 1990 a 2008. Zootecnia Tropical 28, 457-466.

Barth, J. A., Menge, B. A., Lubchenco, J., Chan, F., Bane, J. M., Kirincich, A. R., McManus, M. A., Nielsen, K. J., Pierce, S. D. \& Washburn, L. (2007) Delayed Upwelling Alters Nearshore Coastal Ocean Ecosystems in the Northern California Current. Proceedings of the National Academy of Sciences 104, 3719-3724.

Barton, E. D., Field, D. B. \& Roy, C. (2013) Canary Current Upwelling: More or Less? Progress in Oceanography 116, 167-178.

Ben-Tuvia, A. (1960) Synopsis of Biological Data on Sardinella Aurita of the Mediterranean Sea and Other Waters. Proceedings of the World. Scientific Meeting on the Biology 14, 287-312.

von Bertalanffy, L. (1938) A Quantitative Theory of Organic Growth (Inquiries on Growth Laws. II). Human biology 10, 181-213.

Boëly, T. (1979) Biologie de deux espèces de sardinelles Sardinella aurita Valenciennes, 1847 et Sardinella maderensis Lowe, 1841 des côtes sénégalaises. Thése de doctorat, Paris: Université Paris VI.

Boëly, T. (1982) Etude Du Cycle Sexuel de La Sardinelle Ronde (Sardinella aurita Val. 1847) Au Sénégal. Océanographie tropicale 17, 3-13.

Boëly, T., Fréon, P. \& Stéquert, B. (1982) La Croissance de Sardinella aurita (Val. 1847) Au Sénégal. Oceanographie Tropicale 17, 103-119.

Boltachev, A. R. \& Karpova, E. P. (2014) Faunistic Revision of Alien Fish Species in the Black Sea. Russian journal of biological invasions 5, 225-241.

Brodeur, R. D., Hunsicker, M. E., Hann, A. \& Miller, T. W. (2018) Effects of Warming Ocean Conditions on Feeding Ecology of Small Pelagic Fishes in a Coastal Upwelling Ecosystem: A Shift to Gelatinous Food Sources. Marine Ecology Progress Series.

Chaboud, C., Fall, M., Ferraris, J., Fontana, A., Fonteneau, A., Laloë, F., Samba, A. \& Thiao, D. (2015) Comment on 'Fisheries Catch Misreporting and Its Implications: The Case of Senegal'. Fisheries Research 164, 322-324.

Charouki, N., Sarré, A., Serghini, M., Ebaye, O. S. \& Krakstad, J. O. (2011) Contribution to Acoustic Targets Identification in Northwest Africa by Statistical Schools Properties. In Science and Management of Small Pelagics. Symposium on Science and the Challenge of Managing Small Pelagic Fisheries on Shared Stocks in Northwest Africa pp. 285-294 Rome: FAO.

Chikhi, L. (1995) Différenciation génétique chez Sardinella aurita et $S$. maderensis Allozymes et ADN mitochondrial. Thèse nouveau doctorat, France: Université de Paris 06.

Conand, C. (1977) Contribution À L'étude Du Cycle Sexuel et de La Fécondité de La Sardinelle Ronde, Sardinella aurita: Pêche Sardinière Dakaroise En 1975 et Premier Semestre 1976. Cahiers ORSTOM. Série Océanographie 15, 301-312.

Craney, T. A. \& Surles, J. G. (2002) Model-Dependent Variance Inflation Factor Cutoff Values. Quality Engineering 14, 391-403.

Cury, P. \& Fontana, A. (1988) Compétition et Stratégies Démographiques Comparées de Deux Espèces de Sardinelles (Sardinella aurita et Sardinella maderensis) Des Côtes Ouest-Africaines. Aquatic living resources 1, 165-180. 
Diankha, O., Ba, A., Brehmer, P., Brochier, T., Sow, B. A., Thiaw, M., Gaye, A. T., Ngom, F. \& Demarcq, H. (2018) Contrasted Optimal Environmental Windows for Both Sardinella Species in Senegalese Waters. Fisheries Oceanography 27, 351-365.

Ekman, V. W. (1905) On the Influence of the Earth's Rotation on Ocean-Currents. Arkiv Foer Matematik, Astronomi och Fysik 2, 1-52.

FAO. (2016) Report of the FAO working group on the assessment of small pelagic fish off Northwest Africa Casablanca, Morocco, 20-25 July 2015/Rapport du groupe de travail de la FAO sur l'évaluation des petits pélagiques au large de l'Afrique Nord-Occidentale Casablanca, Maroc, 20-25 juillet 2015 (Casablanca, Maroc: FAO). $\mathrm{N}^{\circ} 1122$. Casablanca, Maroc: FAO. 243 p.

Felder, D. L. (2009) Gulf of Mexico Origin, Waters, and Biota: Biodiversity, College Station. Biodiversity. Texas: Texas A\&M University Press. Vol. 1.

Fontana, A. (1969) Etude de La Maturité Sexuelle Des Sardinelles Sardinella eba (Val) et Sardinella aurita C. et V. de La Région de Pointe-Noire. Cahiers ORSTOM, serie Oceanographique VII, 111-114.

Fréon, P. (1988) Réponses et adaptations des stocks de Clupéidés d'Afrique de l'Ouest à la variabilité du milieu et de l'exploitation: analyse et réflexion à partir de l'exemple du Sénégal. Thése de doctorat, Paris: Université d'Aix Marseille II.

Froese, R. \& Pauly, D. (2016) FishBase: World Wide Web Electronic Publication Version. Gaamour, A., Missaoui, H., Ben-Abdallah, L. \& El Ahmed, A. (2001) Parametres Biologiques de La Sardinelle Ronde (Sardinella aurita Valenciennes, 1847) Dans La Région Du Cap Bon (Canal Siculo-Tunisien). GFCM, Kavala. Greece 2001.

Gassman, J., Eslava, N. \& González, L. W. (2008) Reproducción de La Sardina, Sardinella aurita (Cupleiformes: Clupeidae) Del Sureste de La Isla de Margarita, Venezuela. Revista de biología tropical 56, $1813-1824$. Goudiaby, K. D., Samb, B. \& Sylla, M. (2008) Contribution À La Connaissance de La Biologie Des Sardinelles (Sardinella aurita et Sardinella maderensis) Du Littoral Sénégalais. In Science et aménagement des petits pélagiques. Symposium sur la science et le défi de l'aménagement des pêcheries de petits pélagiques sur les stocks partagés en Afrique nord-occidentale pp. 39-56 Rome: Food and Agriculture Organization of the United Nations.

Haist, V. \& Stocker, M. (1985) Growth and Maturation of Pacific Herring (Clupea Harengus Pallasi) in the Strait of Georgia. Canadian Journal of Fisheries and Aquatic Sciences 42, s138-s146.

Harrell Jr, F. E. (2017) With Contributions from Charles Dupont and Many Others: Hmisc: Harrell Miscellaneous. R Package Version 3.17-2.

Hastie, T. \& Tibshirani, R. (1986) Generalized Additive Models. Statistical Science 1, 297-318.

Isselmou, O. \& Baye, C. (2009) Evaluation et cartographie de l'abondance du stock de la sardinelle ronde dans la zone Nord-Ouest Africaine. Thèse de maîtrise, Pôle Halieutique (Agrocamus Ouest) et CRH de Sète.

Koutrakis, E. T. \& Tsikliras, A. C. (2003) Length-weight Relationships of Fishes from Three Northern Aegean Estuarine Systems (Greece). Journal of Applied Ichthyology 19, 258-260.

Le Bec, C. (1983) Cycle Sexuel et Fécondité de La Sole Solea Vulgaris (Quensel, 1806) Du Golfe de Gascogne. Revue des travaux de l'Institut des pêches maritimes 47, 179-189.

Le Cren, E. D. (1951) The Length-Weight Relationship and Seasonal Cycle in Gonad Weight and Condition in the Perch (Perca Fluviatilis). The Journal of Animal Ecology 20, 201-219.

MacCall, A. D. (2009) Mechanisms of Low-Frequency Fluctuations in Sardine and Anchovy Populations. In Climate Change and Small Pelagic Fish pp. 285-299 Cambridge: Cambridge University Press.

Mackas, D. L., Peterson, W. T., Ohman, M. D. \& Lavaniegos, B. E. (2006) Zooplankton Anomalies in the California Current System before and during the Warm Ocean Conditions of 2005. Geophysical Research Letters 33, S07.

McQuinn, I. H., Cleary, L. \& O’Boyle, R. N. (1990) Estimation de La Mortalité Naturelle. In Méthodes d'évaluation des stocks halieutiques pp. 441- 464 Nouvelle- Ecosse, Canada: Projet CIEO-860060, Centre International d'Exploitation des Oceans, Halifex.

Mendoza, J. J., Fréon, P. \& Guzmán, R. (1994) VPA Estimates of Fishing Mortality and Exploited Biomass from Sardinella Aurita Catch-at-Length Data in Eastern Venezuela. NAGA, the ICLARM quarterly 17, 32-36. Mildenberger, T. K., Taylor, M. H. \& Wolff, M. (2017) Extending ELEFAN in R. Figshare.

Ndoye, S., Capet, X., Estrade, P., Sow, B., Machu, E., Brochier, T., Döring, J. \& Brehmer, P. (2017) Dynamics of a 'low-enrichment High-retention' Upwelling Center over the Southern Senegal Shelf. Geophysical Research Letters 44.

Pauly, D. (1983) Some Simple Methods for the Assessment of Tropical Fish Stocks. Fisheries Report 234. Food and Agriculture Organization of the United Nations. 52. 
Peck, M. A., Reglero, P., Takahashi, M. \& Catalán, I. A. (2013) Life Cycle Ecophysiology of Small Pelagic Fish and Climate-Driven Changes in Populations. Progress in Oceanography 116, 220-245.

Postel, E. (1955) Résumé Des Connaissances Acquises Sur Les Clupéidés de l'Ouest Africain. Rapp. Rapport Conseil d'Exploration de La Mer 137, 14-17.

Puerta, P., Hunsicker, M. E., Quetglas, A., Álvarez-Berastegui, D., Esteban, A., González, M. \& Hidalgo, M. (2015) Spatially Explicit Modeling Reveals Cephalopod Distributions Match Contrasting Trophic Pathways in the Western Mediterranean Sea. PloS one 10, e0133439.

Roy, C., Cury, P., Fontana, A. \& Belvèze, H. (1989) Stratégies Spatio-Temporelles de La Reproduction Des Clupéidés Des Zones D’upwelling d'Afrique de l'Ouest. Aquatic Living Resources 2, 21-29.

Samba, O. (2011) Nouvelle évaluation des caractéristiques biologiques de Sardinella aurita (valenciennes, 1847) et sardinella maderensis (lowe, 1841). Mémoire DEA, Senegal: Université Cheikh Anata Diop de Dakar (UCAD). Sarré, A., Krakstad, J.-O., Brehmer, P. \& Mbye, E. M. (2018) Spatial Distribution of Main Clupeid Species in Relation to Acoustic Assessment Surveys in the Continental Shelves of Senegal and The Gambia. Aquatic Living Resources 31, 9.

Stergiou, K. I. (2000) Life-History Patterns of Fishes in the Hellenic Seas. Web ecology 1, 1-10. Sylla, M., Brochier, T., Pecquerie, L., Ndiaye, O., Richaume, M. \& Brehmer, P. (2016) Senegalese Sardinella aurita from 1995 to 2011: Review of Size Spectra, Sex Ratio, Gonadal Somatic and Condition Indexes from Small Scale Main National Landing Sites. In Brehmer Patrice (Ed.), Ba B. (Ed.), Kraus G. (Ed.) pp. 51-51 Dakar, Senegal: SRFC/CSRP; IRD.

Thiao, D. (2009) Un système d'indicateurs de durabilité des pêcheries côtières comme outil de gestion intégrée des ressources halieutiques sénégalaises. Ph.D. Thesis, France: Université de Versailles Saint-Quentin-enYvelines.

Thiaw, M., Auger, P.-A., Sow, F. N., Brochier, T., FAYE, S., Diankha, O. \& Brehmer, P. (2017) Effect of Environmental Conditions on the Seasonal and Inter-Annual Variability of Small Pelagic Fish Abundance off North-West Africa: The Case of Both Senegalese Sardinella. Fisheries Oceanography 26, 583-601. Thomas, A. C. \& Brickley, P. (2006) Satellite Measurements of Chlorophyll Distribution during Spring 2005 in the California Current. Geophysical Research Letters 33.

Tiedemann, M. \& Brehmer, P. (2017) Larval Fish Assemblages across an Upwelling Front: Indication for Active and Passive Retention. Estuarine, Coastal and Shelf Science 187, 118-133.

Tsikliras, A. C. (2004) Biology and Population Dynamics of Round Sardinella (Sardinella aurita Valenciennes, 1847) in Kavala Gulf (Northern Aegean Sea, Greece). Ph.D. Thesis, Greece: Aristotle University of Thessaloniki. Tsikliras, A. C. \& Antonopoulou, E. (2006) Reproductive Biology of Round Sardinella (Sardinella aurita) in North-Eastern Mediterranean. Scientia Marina 70, 281-290.

Tsikliras, A. C., Koutrakis, E. T. \& Stergiou, K. I. (2005) Age and Growth of Round Sardinella (Sardinella aurita) in the Northeastern Mediterranean. Scientia marina 69, 231-240.

Wague, A. \& Mbodj, O. B. (2002) Etude de Quelques Aspects de La Reproduction Chez La Sardinelle Ronde Sardinella aurita (Valenciennes, 1847) Pechee Le Long Des Côtes Mauritaniennes. Bulletin Scientifique de l'Institut Mauritanien de Recherches Océanographiques et des Pêches 13-18.

WECAFC, W. C. A. F. (2014) Status of the stocks of the Western Central Atlantic-FAO statistical area 31.Port of Spain, Trinidad and Tobago, 26-28 March 2014. Fifteenth session. Port of Spain, Trinidad and Tobago: FAO. 9. Wood, S. \& Wood, M. S. (2017) Package 'mgcv'. R package version 1-7. Wootton, R. J. (1998) Ecology of Teleost Fishes, 2nd ed. Dordrecht: Kuwer Academic Publishers. Zuur, A. F., Ieno, E. N. \& Elphick, C. S. (2010) A Protocol for Data Exploration to Avoid Common Statistical Problems. Methods in ecology and evolution 1, 3-14. 
571 FIG. 1: Map of the study area with the localization of sampling stations corresponding to the main 572 landing ports along the Senegal coast. The northern section includes Saint-Louis, Kayar, and Yoff; the 573 southern section includes the "Petite côte" (Hann, Mbour, and Joal) and Casamance (Kafountine). 574 Gambian EEZ was not taking into account in the study, neither were Mauritanian EEZ and Bissau 575 Guinean EEZ.

576 FIG. 2: Size frequency distributions for Sardinella aurita caught off the Senegal coast from July 2013 to 577 June 2014. Total length was used. Three modes exist in the frequency data: one for fish located off the 578 northern coast (black) (32 cm, $\mathrm{n}=10.109)$ and two for fish caught off the southern coast (grey) (13 and $57924 \mathrm{~cm}, \mathrm{n}=22.237)$.

580 FIG. 3: Length-weight relationships for Sardinella aurita caught off the coast of Senegal (data: 1995 to $5812011 ; n=4397)$. The black line is the exponential regression curve fitted to all measurements.

582 FIG. 4: Sardinella aurita condition factor (Kn) data (black line), combined to seasonal environmental 583 components for Senegal coastal waters (1995 to 2011): coastal Sea Surface Temperature (dashed 584 line) (Modis AVHRR) and Coastal Upwelling Index (grey line). (a) Monthly and (b) annual mean data.

585 FIG. 5: Condition factor (Kn) of Sardinella aurita as a function of Coastal Upwelling Index (CUI) 586 throughout the study (1995-2011).

587 FIG. 6: Auximetric plot (double logarithmic plot of parameters $K$ and $L_{\infty}$ ) for Sardinella aurita 588 populations for four coastal areas. Data from this study in Senegal (square) and from a literature review 589 of Eastern Central Atlantic (circles), Mediterranean Sea (triangles) and Western Central Atlantic (plus 590 signs). Abbreviations: $L_{\infty}$ : (asymptotic length, in $\mathrm{cm}$ ) and $\mathrm{K}$ : [coefficient of growth rate (by year)].

591 FIG. 7: Monthly sexual maturity stages (sensu Fontana 1969) for Sardinella aurita off the Senegal 592 coast (1995 to 2011). (a) female $(n=2131)$ and (b) male $(n=2266)$ 
593 FIG. 8: Gonado-somatic index (GSI) for Sardinella aurita in Senegal coastal waters (1995 to 2011). (a) 594 female $(n=2131)$ and $(b)$ male $(n=2266)$. Means are represented by the horizontal line inside the box 595 plots. Standard errors are represented by circles. 


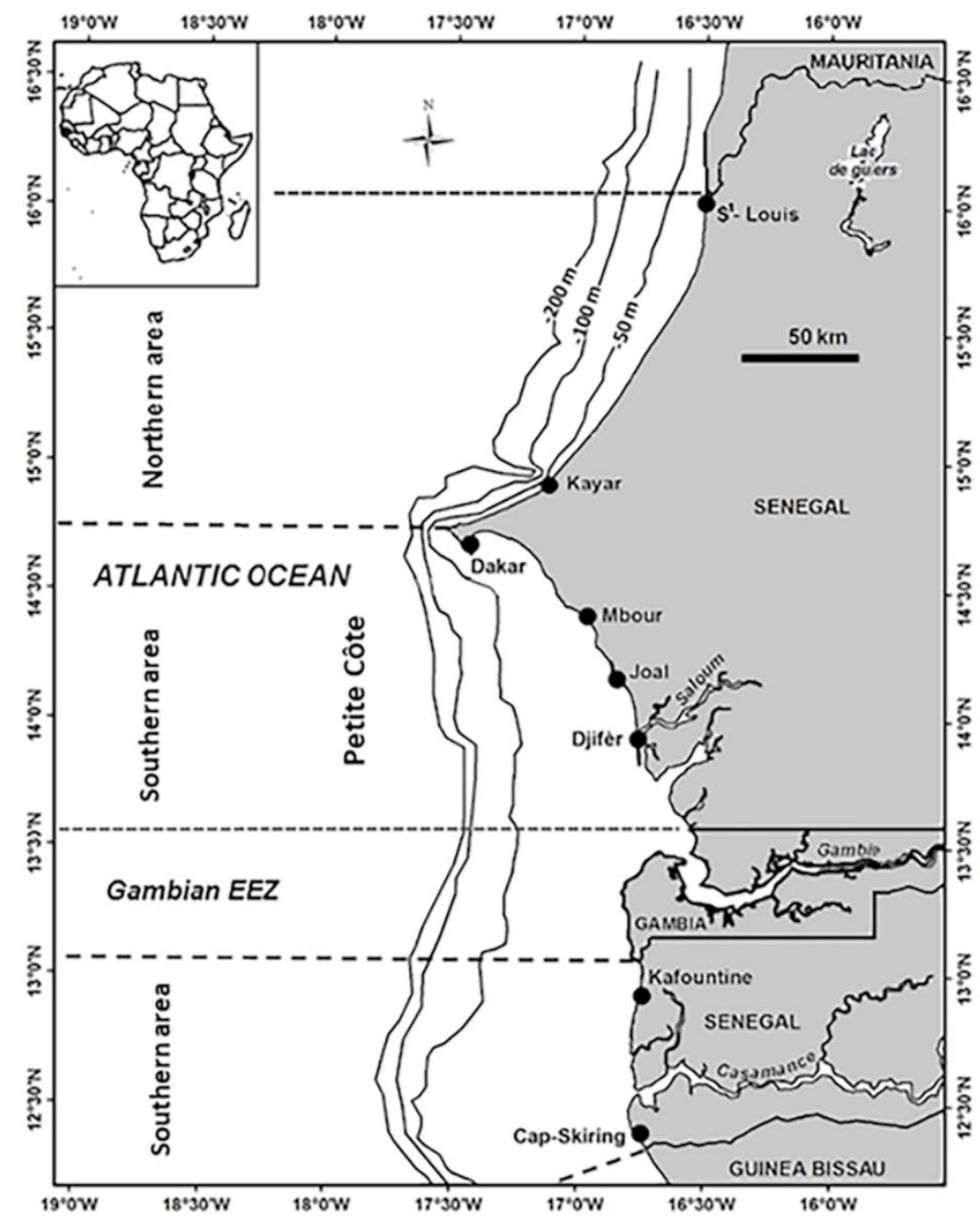

598

599 FIG. 1 


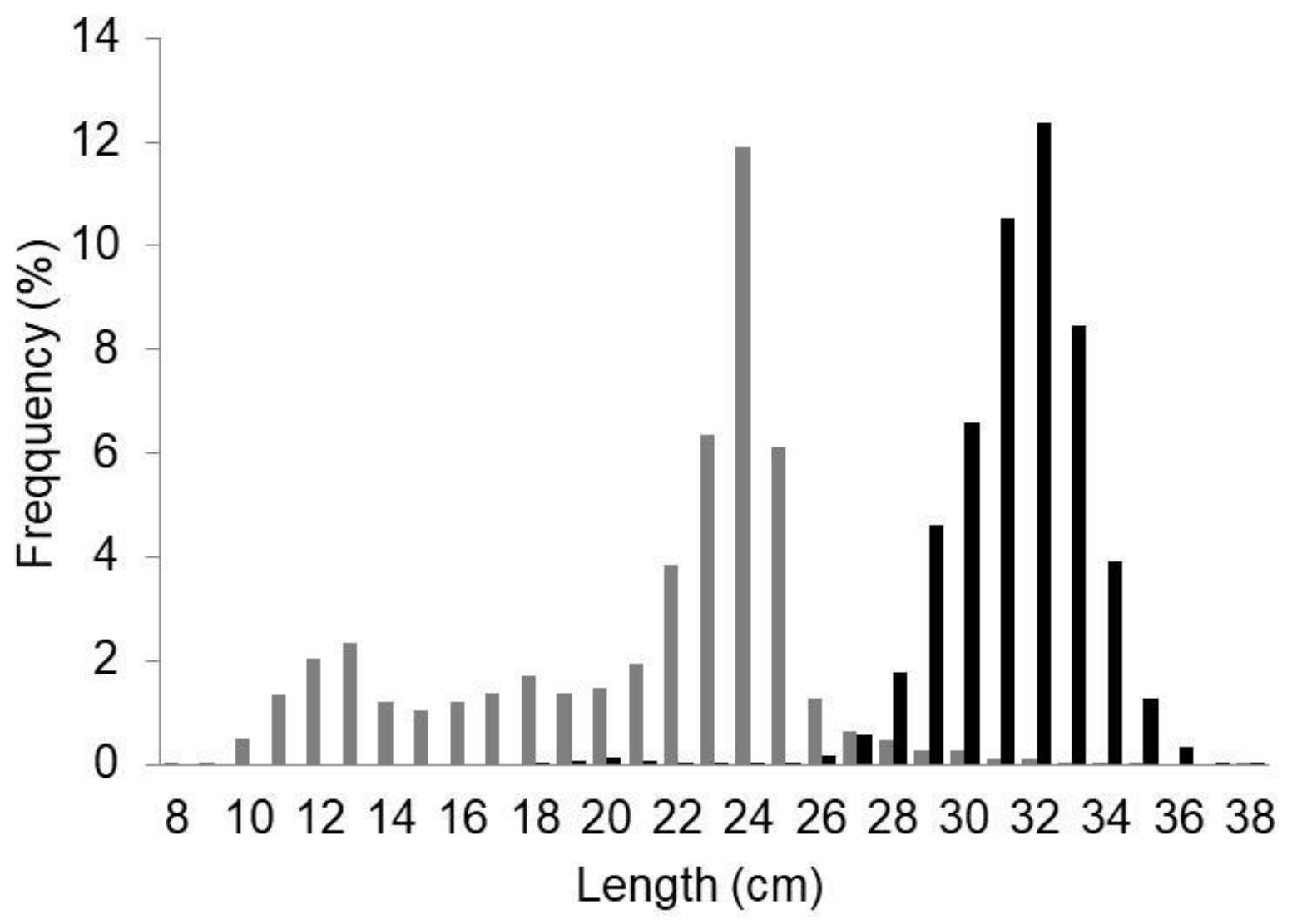

601

602 FIG. 2

603 


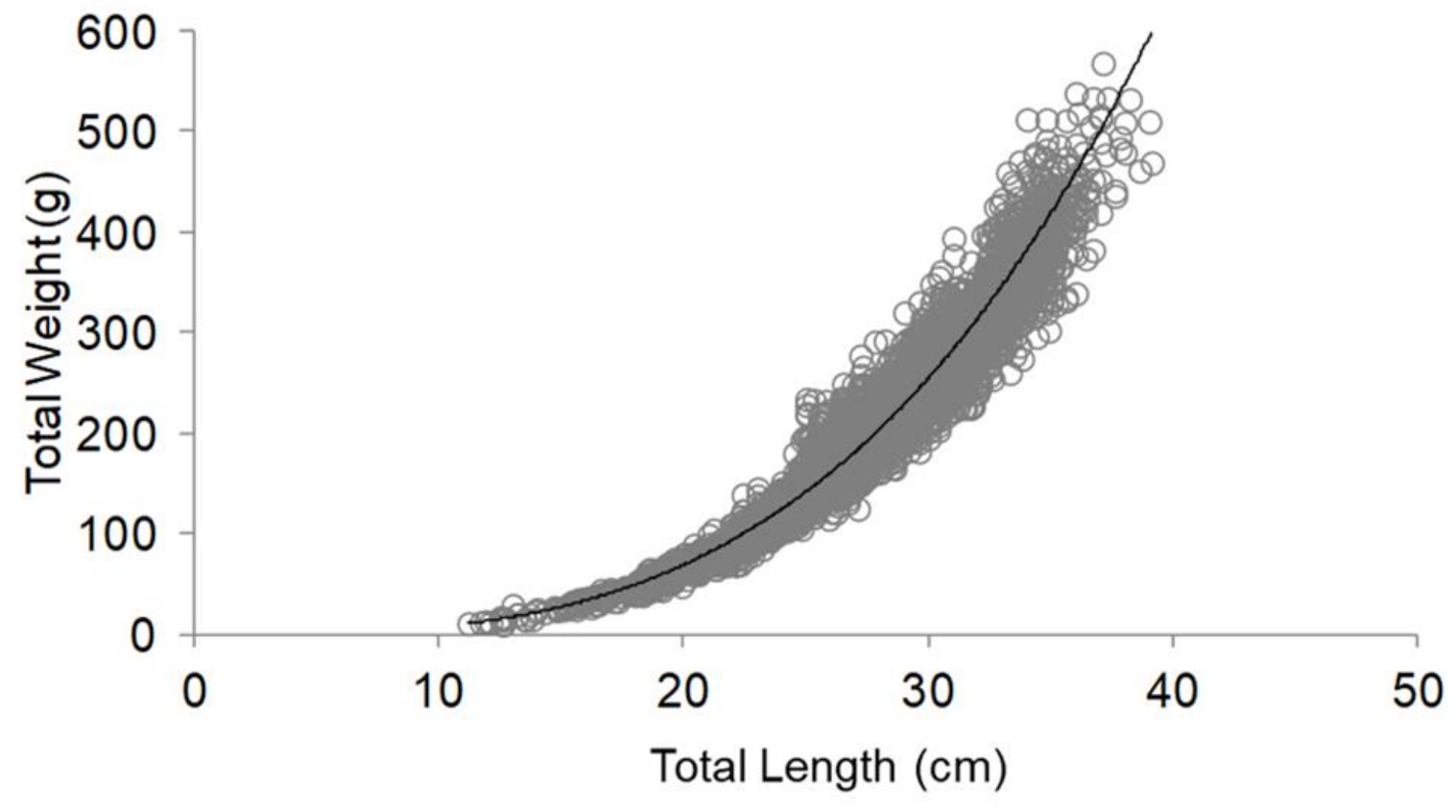

604

605 FIG. 3

606 


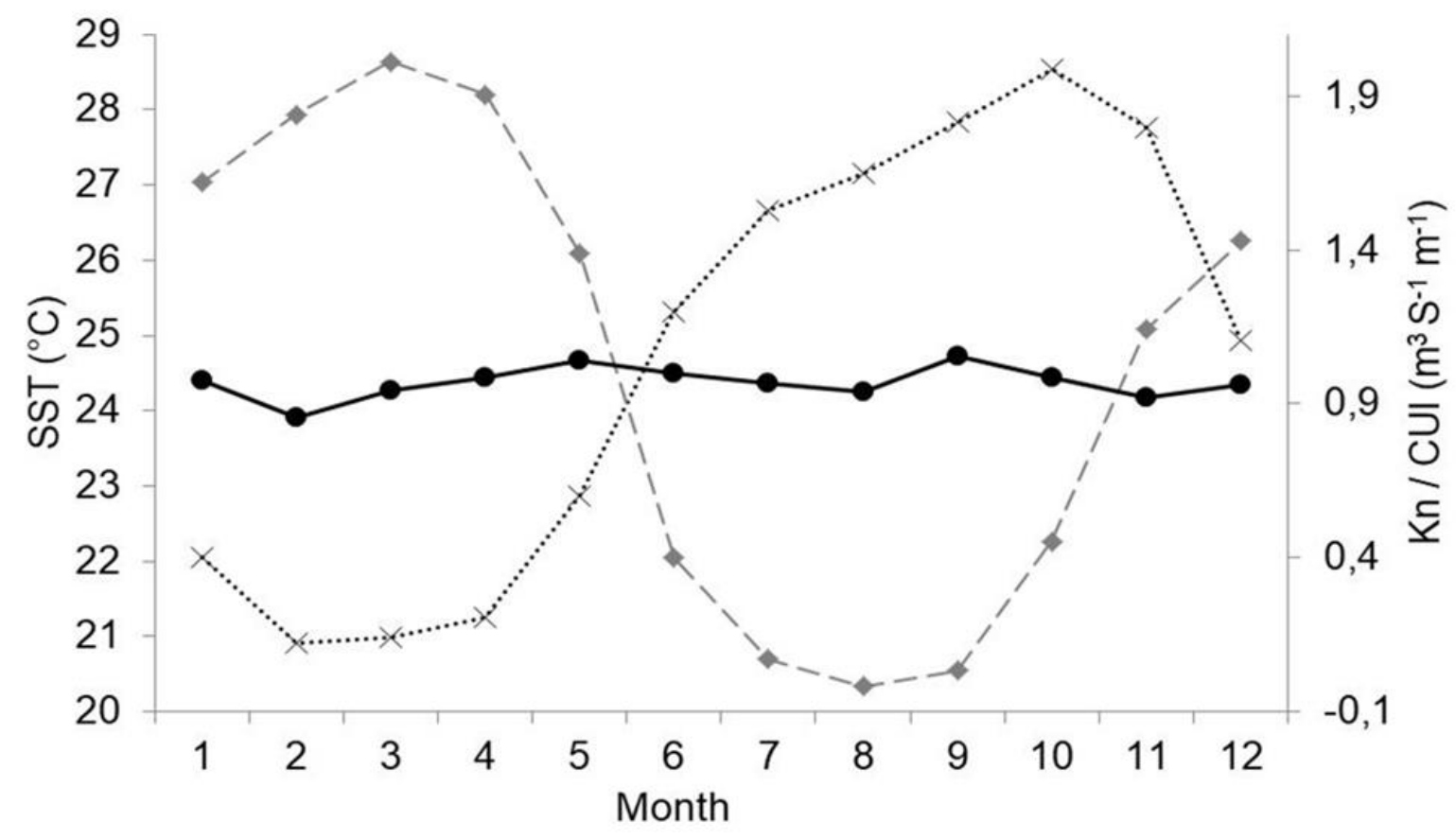

607

$608 \quad$ a)

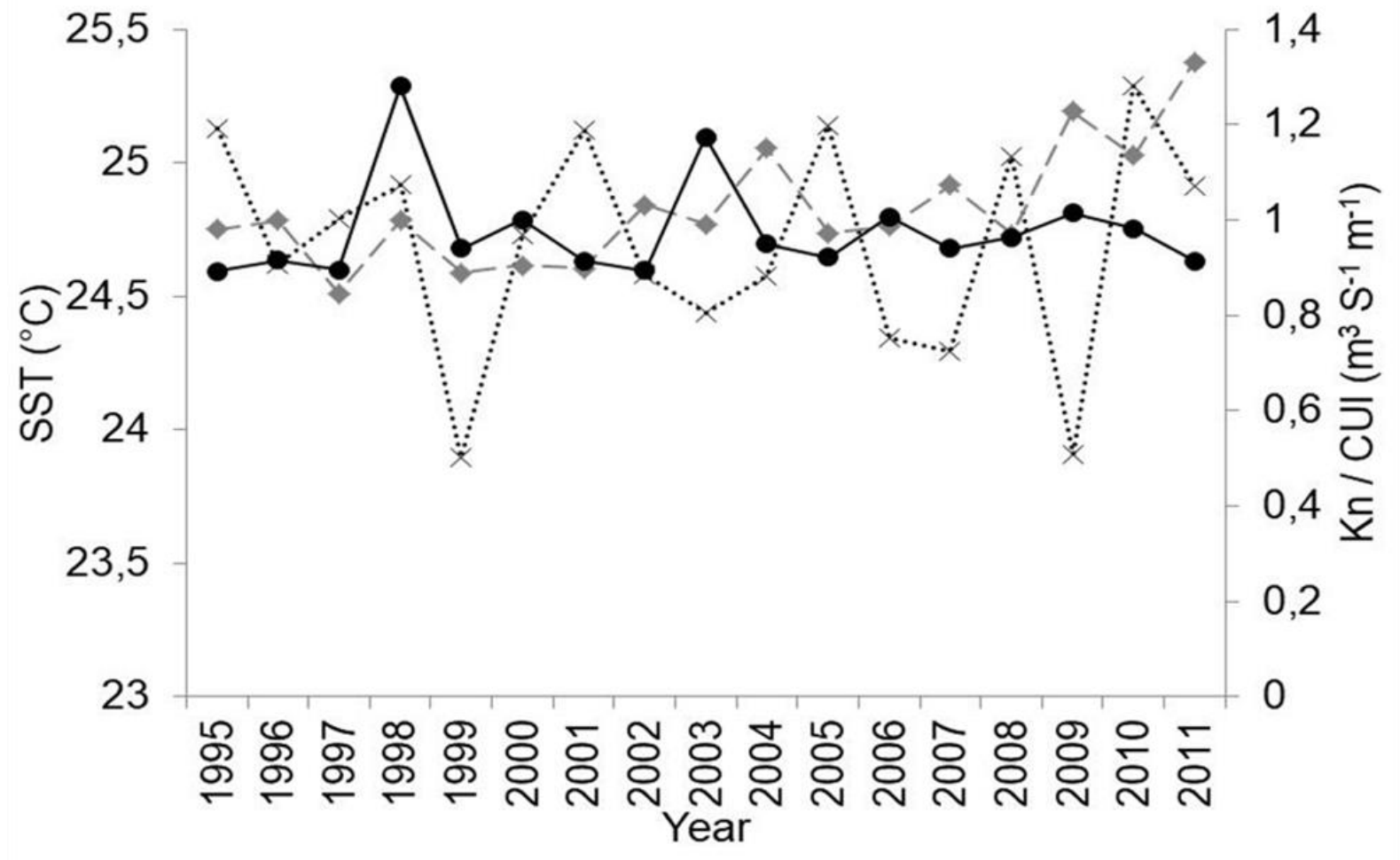

609

610 b)

611 FIG. 4

612

613 


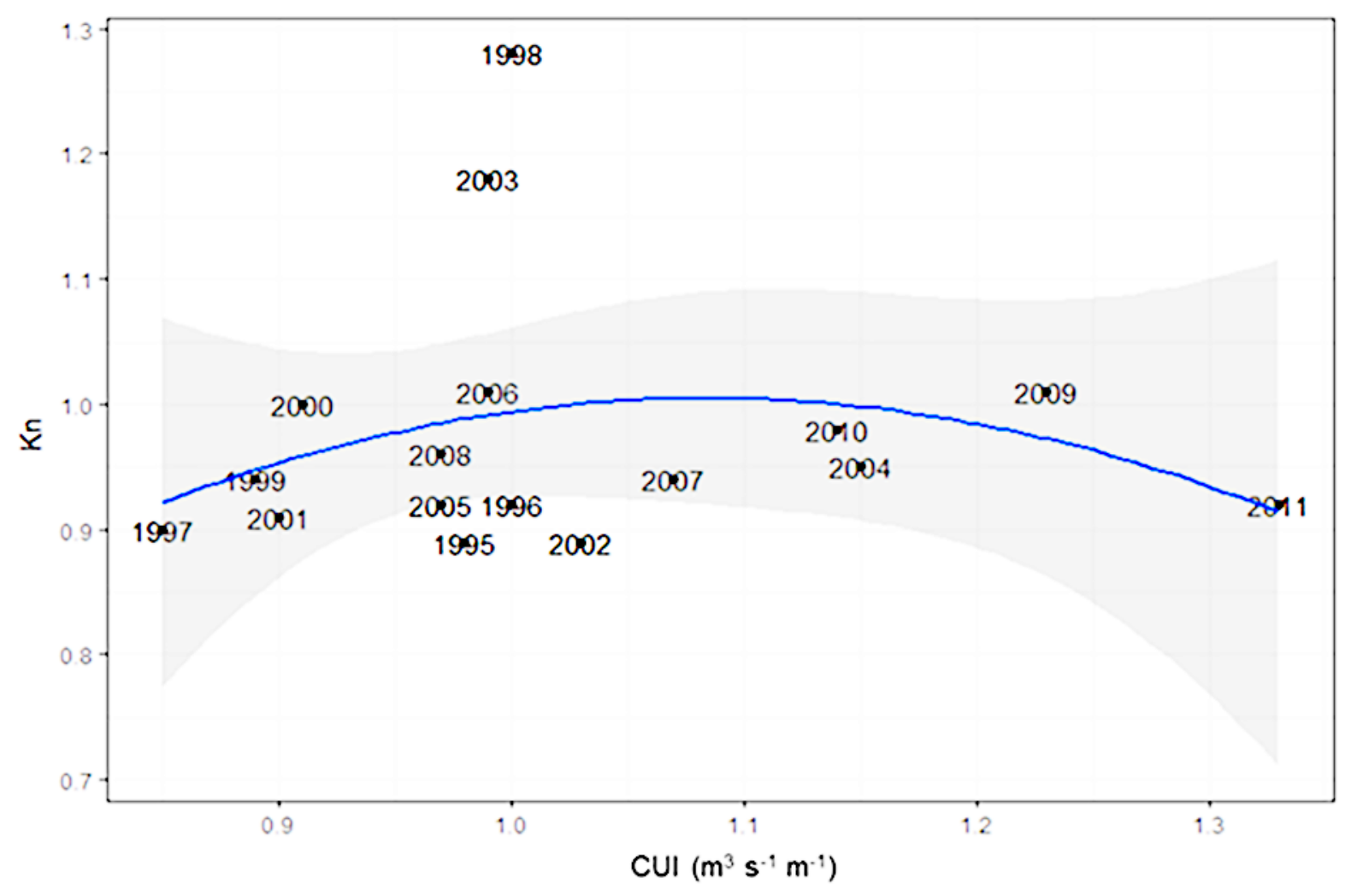

614

615 FIG. 5

616 


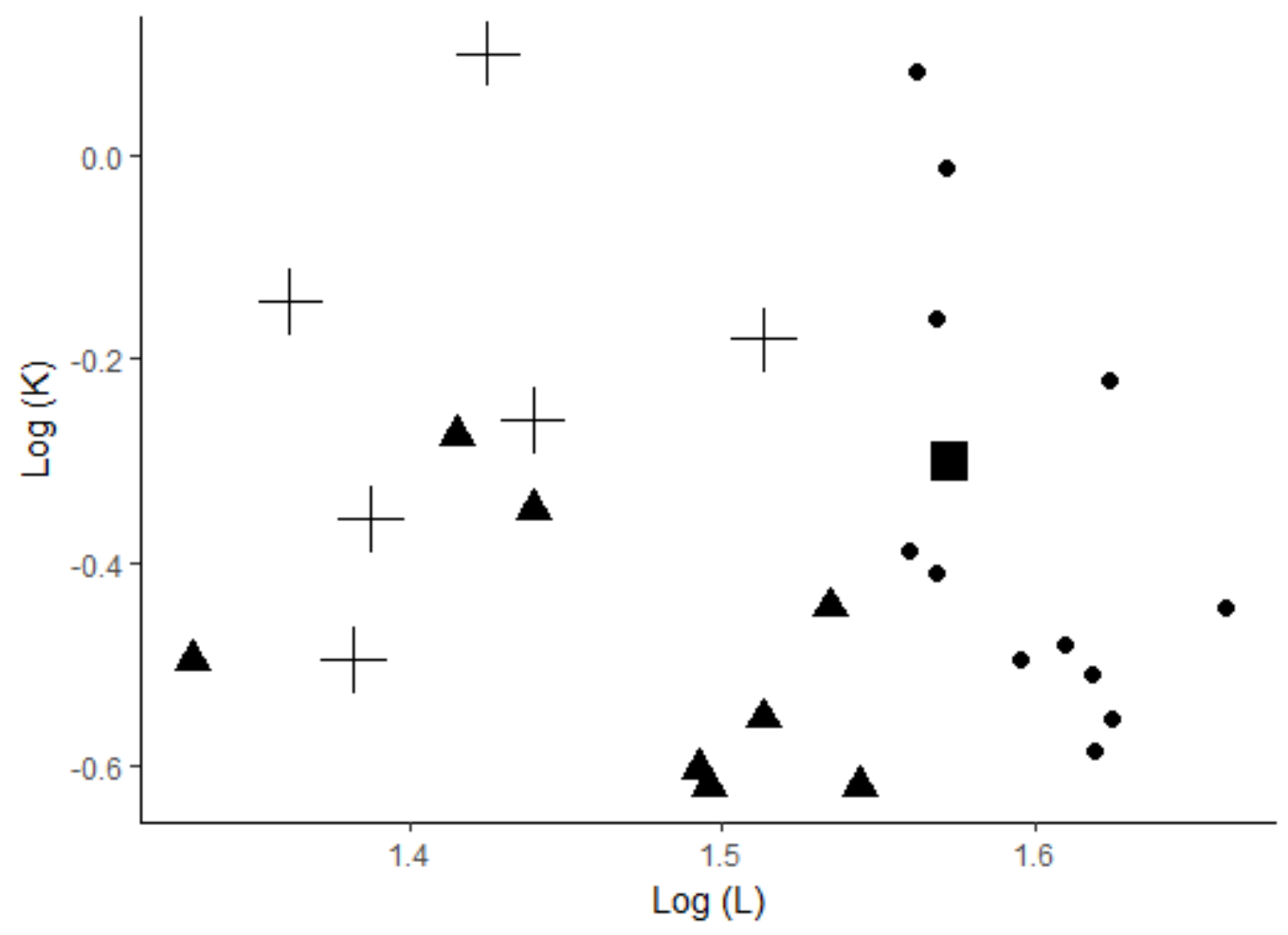

617

618 FIG. 6

619 


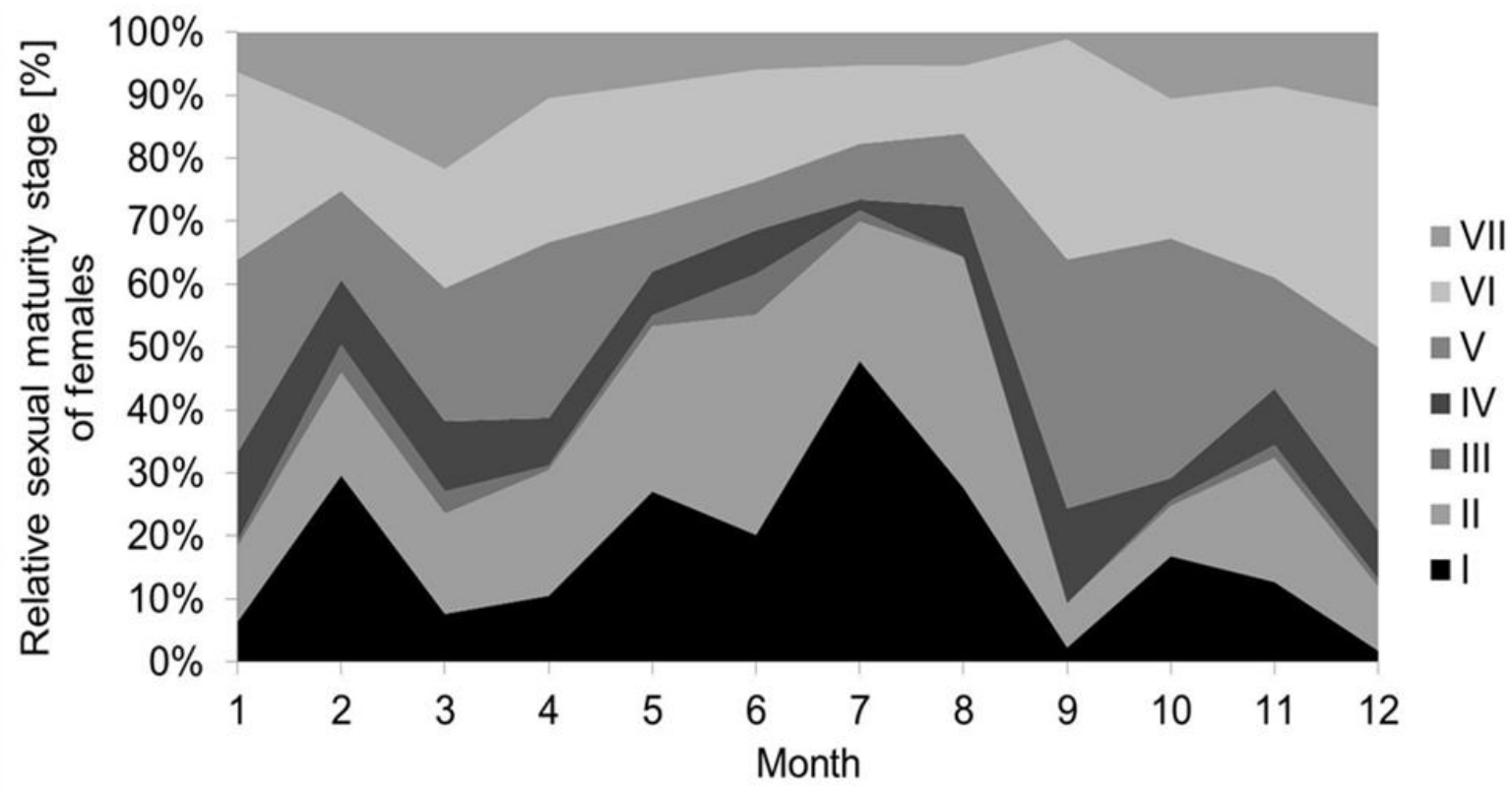

621

622 a)

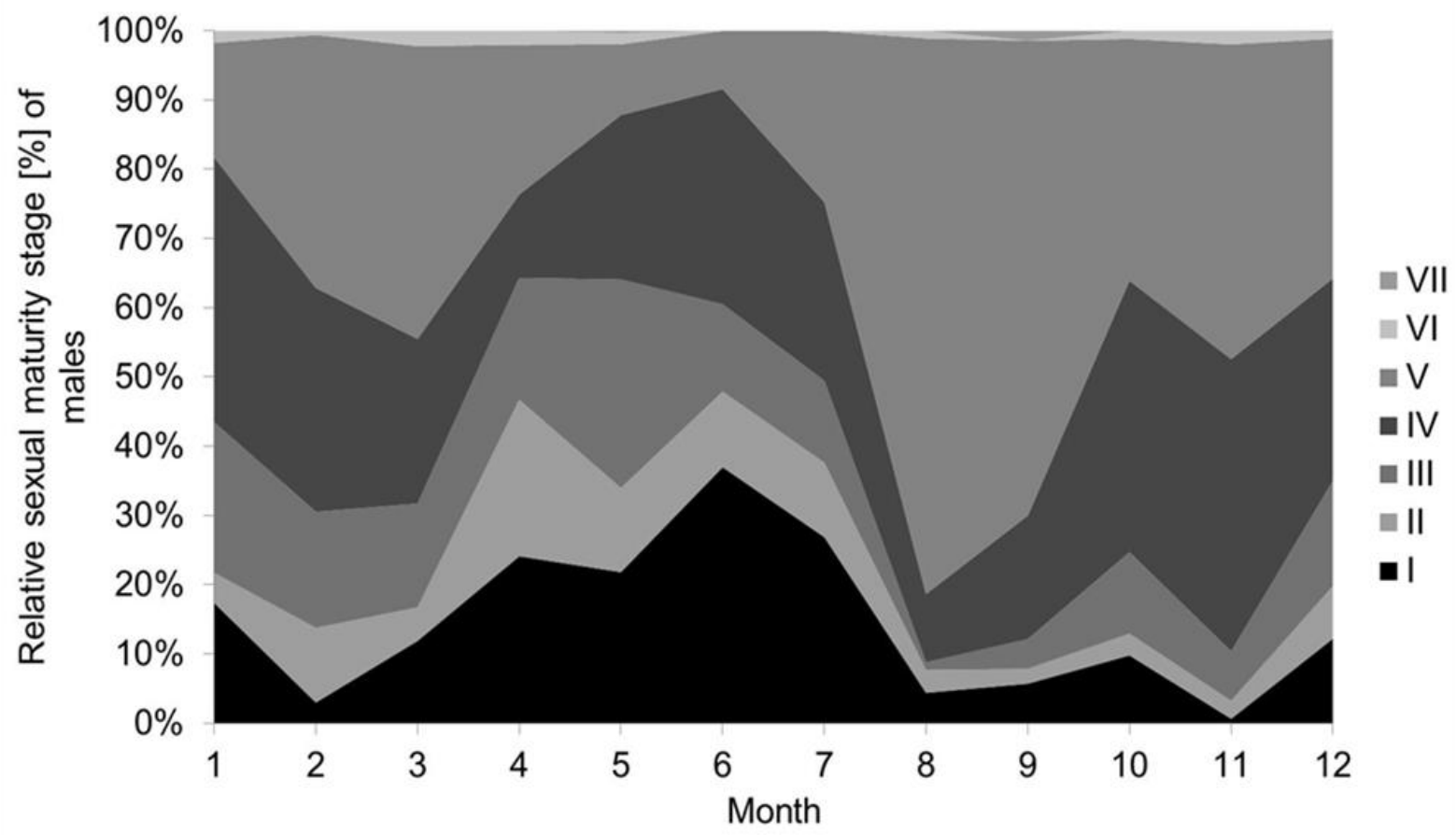

623

624 b)

625 FIG. 7 


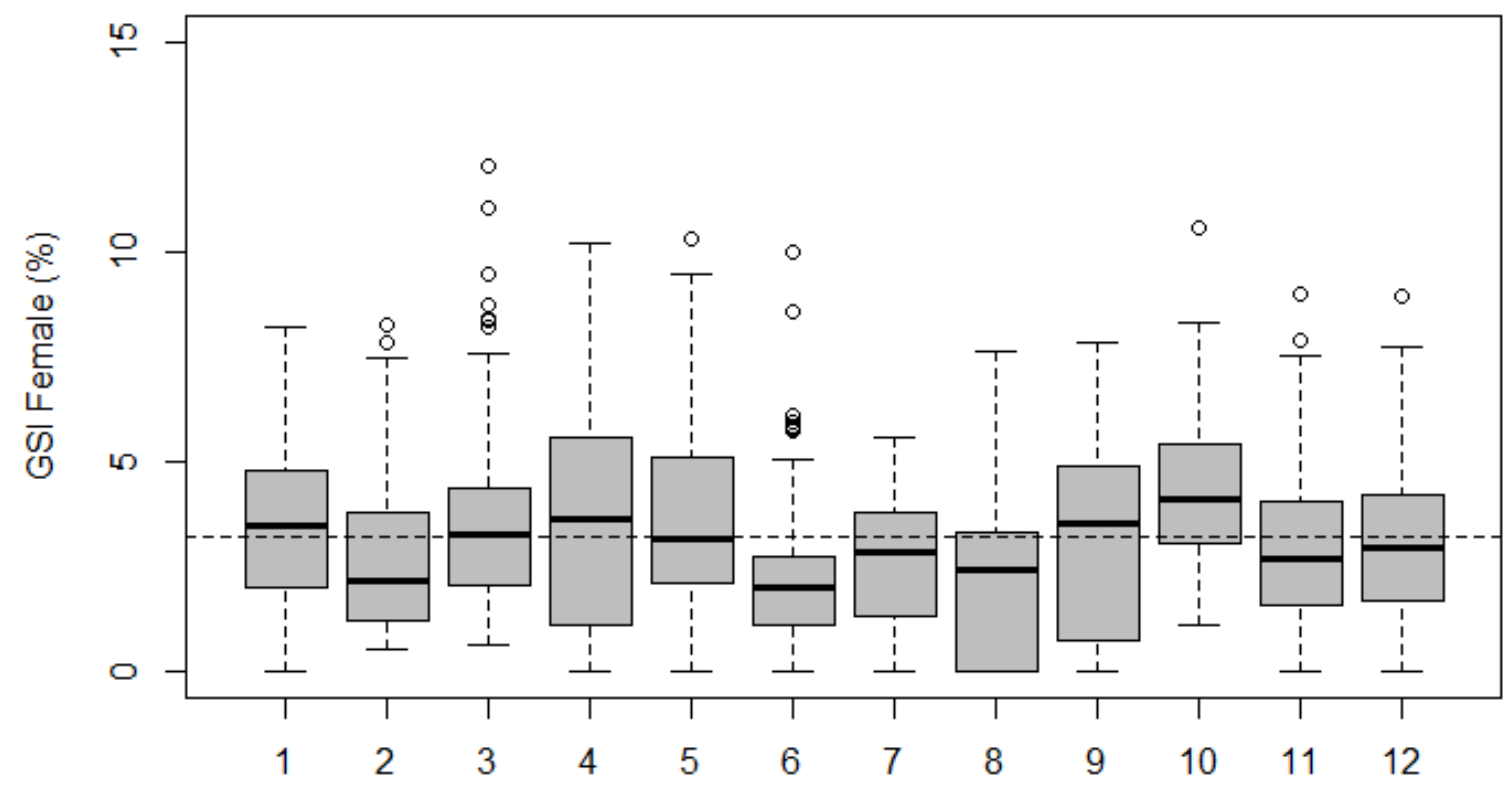

627

Month

628 a)

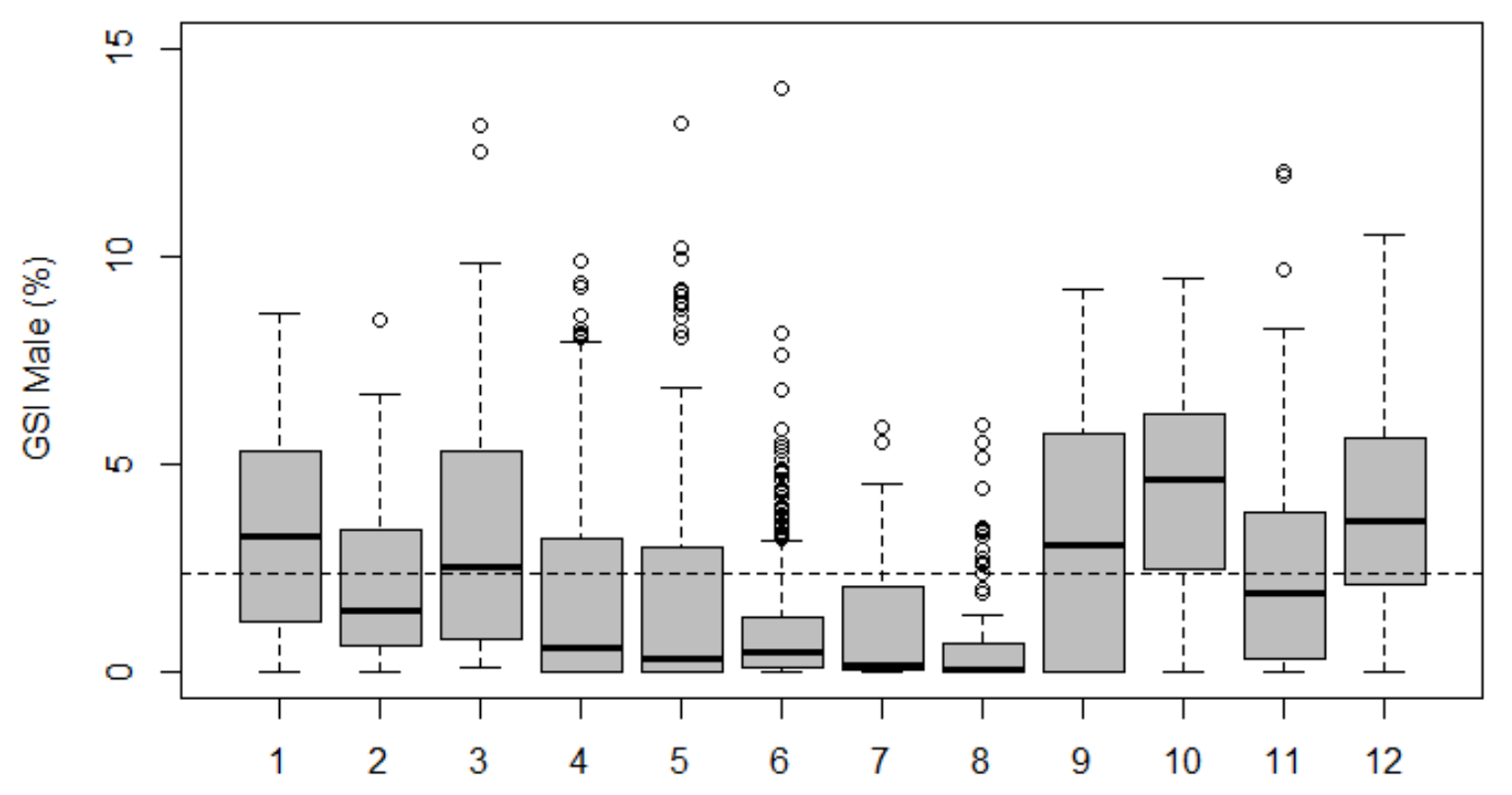

629

Month

630 b)

631 FIG. 8

632 
633 TABLE I: Sardinella aurita. Number of monthly observations for all variables except weight, by sex 634 and maturity stages.

\begin{tabular}{|c|c|c|c|c|c|c|c|c|c|c|c|c|c|c|}
\hline & \multicolumn{14}{|c|}{ Month } \\
\hline & & 1 & 2 & 3 & 4 & 5 & 6 & 7 & 8 & 9 & 10 & 11 & 12 & Total \\
\hline \multirow{3}{*}{ Sex } & $\mathrm{F}$ & 219 & 135 & 170 & 276 & 229 & 401 & 113 & 112 & 86 & 113 & 244 & 168 & 2266 \\
\hline & $\mathrm{M}$ & 209 & 115 & 167 & 227 & 199 & 362 & 119 & 93 & 91 & 140 & 255 & 154 & 2131 \\
\hline & Total & 428 & 250 & 337 & 503 & 428 & 763 & 232 & 205 & 177 & 253 & 499 & 322 & 4397 \\
\hline \multirow{8}{*}{ Stages } & I & 22 & 60 & 18 & 56 & 110 & 160 & 98 & 56 & 6 & 27 & 56 & 4 & 673 \\
\hline & II & 33 & 27 & 45 & 66 & 105 & 184 & 38 & 51 & 9 & 12 & 56 & 21 & 647 \\
\hline & III & 28 & 31 & 34 & 36 & 39 & 135 & 17 & 11 & 1 & 7 & 35 & 13 & 387 \\
\hline & IV & 91 & 58 & 73 & 75 & 40 & 114 & 39 & 33 & 22 & 29 & 122 & 78 & 774 \\
\hline & $\mathrm{V}$ & 175 & 38 & 97 & 173 & 64 & 68 & 20 & 36 & 107 & 139 & 132 & 119 & 1168 \\
\hline & $\mathrm{VI}$ & 65 & 18 & 33 & 68 & 51 & 77 & 14 & 12 & 31 & 25 & 77 & 67 & 538 \\
\hline & VII & 14 & 18 & 37 & 29 & 19 & 25 & 6 & 6 & 1 & 14 & 21 & 20 & 210 \\
\hline & Total & 428 & 250 & 337 & 503 & 428 & 763 & 232 & 205 & 177 & 253 & 499 & 322 & 4397 \\
\hline
\end{tabular}


637 Fontana (1969).

\begin{tabular}{|c|c|c|}
\hline Stage & State & Description \\
\hline I & Immature & $\begin{array}{l}\text { Female gonad small and firm, transparent or light pink, invisible oocytes. } \\
\text { Male gonad white or slightly translucent, very fine. }\end{array}$ \\
\hline II & Rest & Characteristics of female and male gonads substantially identical to Stage I. \\
\hline III & Maturation start & $\begin{array}{l}\text { Female gonad, firm and of color varying from pale pink to light orange, } \\
\text { some oocytes are sometimes visible through the ovarian membrane. } \\
\text { Male gonad whitish firm, no liquid will flow if an incision is made. }\end{array}$ \\
\hline IV & Pre-egg / pre-release & $\begin{array}{l}\text { Female gonad bigger and less firm usually light orange then dark. Oocytes } \\
\text { visible through the ovarian membrane make the surface of the ovary granular } \\
\text { Male gonad softer and white. A whitish liquid flows as soon as an incision is } \\
\text { made. }\end{array}$ \\
\hline $\mathrm{V}$ & $\begin{array}{l}\text { Sperm laying / } \\
\text { Emission }\end{array}$ & $\begin{array}{l}\text { Female gonad very large occupying the entire abdominal cavity. } \\
\text { Very fine ovarian membrane. Hyaline and large-sized ovules are perfectly } \\
\text { visible and are expelled at the slightest pressure on the abdomen. } \\
\text { Large and soft male gonad. The sperm flows at the slightest pressure } \\
\text { exerted on the abdomen. }\end{array}$ \\
\hline VI & $\begin{array}{l}\text { End of spawning / } \\
\text { Emission and recovery } \\
\text { before subsequent } \\
\text { spawning }\end{array}$ & $\begin{array}{l}\text { The female ovary is flask very vascularized. Its color varies from pink salmon to } \\
\text { red. Through the ovarian membrane the oocytes of } 460 \text { micrometers are } \\
\text { perfectly visible. Numerous hyaline spaces / Flaccid male gonad with a very fine } \\
\text { vascularization especially in the posterior part. }\end{array}$ \\
\hline VII & $\begin{array}{l}\text { End of the last laying / } \\
\text { Emission and } \\
\text { involution of the ovary }\end{array}$ & $\begin{array}{l}\text { Female ovary completely collapsed very flaccid of red color due to a very strong } \\
\text { vascularization. At this stage, the ovary has the characteristic appearance of an } \\
\text { empty bag. Male gonad very flaccid, exhausted and strongly vascularized. }\end{array}$ \\
\hline
\end{tabular}



test + : $<0.05$.

641

\begin{tabular}{|c|c|c|c|c|}
\hline Stages & Female $(\%)$ & Male $(\%)$ & $X^{2}$ & $p$-value \\
\hline I & 56.8 & 43.2 & $2.658 \mathrm{E}+09$ & + \\
\hline II & 66.6 & 33.4 & $1.0519 \mathrm{e}+10$ & + \\
\hline III & 12.6 & 87.4 & $2.188 \mathrm{e}+10$ & + \\
\hline IV & 20.8 & 79.2 & $2.2785 \mathrm{e}+10$ & + \\
\hline V & 34.9 & 65.1 & $6.424 \mathrm{E}+09$ & + \\
\hline VI & 93.2 & 6.8 & $2.9401 \mathrm{e}+10$ & + \\
\hline VII & 98.9 & 1.1 & $1.3085 \mathrm{e}+10$ & + \\
\hline
\end{tabular}




\section{Appendix}

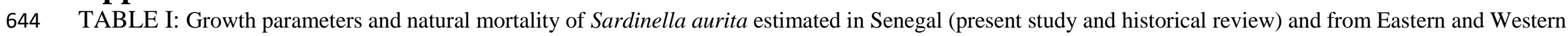

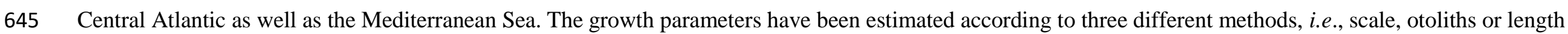

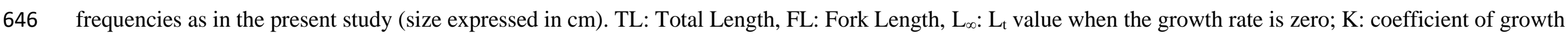

647 rate, $\mathrm{t}_{0}$ : the time “ $\mathrm{t}$ ” when the fish length is zero, $\varphi$ ': growth performance index, M: natural mortality, $\mathrm{t}_{\mathrm{max}}$ : the longevity of the species. NR: not reported.

\begin{tabular}{|c|c|c|c|c|c|c|c|c|c|}
\hline \multirow{2}{*}{ Country } & \multirow{2}{*}{ Method } & $\mathrm{L}_{\infty}$ & $\mathrm{L}_{\infty}$ & \multirow{2}{*}{$\mathrm{K}$} & \multirow{2}{*}{$\mathrm{t}_{0}$} & \multirow{2}{*}{$\varphi^{\prime}$} & \multirow{2}{*}{$\mathrm{t}_{\max }$} & \multirow{2}{*}{ M } & \multirow{2}{*}{ References } \\
\hline & & $\mathrm{FL}$ & TL & & & & & & \\
\hline \multicolumn{10}{|c|}{ Western Central Atlantic } \\
\hline Brazil & Scales & 20.7 & 24.4 & 0.44 & -0.39 & 2.42 & 6.42 & 0.46 & Matsuura (1971) \\
\hline Brazil & Otoliths & 19.6 & 23.0 & 0.72 & -0.25 & 2.58 & 3.91 & 0.76 & Saccardo et al. (1988) \\
\hline Brazil & Otoliths & 23.2 & 27.5 & 0.55 & -0.30 & 2.62 & 5.15 & 0.58 & Cergole et al. (2002) \\
\hline Venezuela & NR & 20.5 & 24.1 & 0.32 & -0.55 & 2.27 & 8.82 & 0.34 & Heald \& Griffiths (1967) \\
\hline Venezuela & Length frequencies & 22.5 & 26.6 & 1.26 & -0.13 & 2.95 & 2.25 & 1.33 & Mendoza et al. (1994) \\
\hline Venezuela & Length frequencies & 27.3 & 32.6 & 0.66 & -0.05 & 2.85 & 4.48 & 0.66 & Barrios et al. (2010) \\
\hline \multicolumn{10}{|c|}{ Mediterranean } \\
\hline Algeria & Length frequencies & 29.3 & 35.0 & 0.24 & -0.70 & 2.47 & 12.01 & 0.24 & Bouaziz et al. (2001) \\
\hline Croatia & Length frequencies & 28.6 & 34.2 & 0.36 & -0.94 & 2.62 & 7.39 & 0.40 & Mustać and Sinovčić (2012a) \\
\hline Egypt & NR & 22.0 & 26.0 & 0.53 & 0.34 & 2.55 & 5.00 & 0.60 & El-Maghraby et al. (1970) \\
\hline Greece & Scales & 27.3 & 32.6 & 0.28 & -0.57 & 2.47 & 10.14 & 0.29 & Ananiades (1952) \\
\hline Greece & Scales & 18.3 & 21.4 & 0.32 & -0.55 & 2.17 & 8.82 & 0.34 & Tsikliras et al. (2005) \\
\hline Israel & Length frequencies & 26.1 & 31.1 & 0.25 & -1.80 & 2.38 & 10.20 & 0.29 & Ben Tuvia (1956) \\
\hline Spain & Length frequencies & 23.2 & 27.5 & 0.45 & -0.38 & 2.53 & 6.28 & 0.47 & Navarro (1932) \\
\hline Tunisia & Otolith & 26.3 & 31.3 & 0.24 & -2.50 & 2.37 & 10.00 & 0.30 & Gaamour et al. (2001) \\
\hline \multicolumn{10}{|c|}{ Eastern Central Atlantic } \\
\hline Canary Islands & Length frequencies & 34.6 & 41.5 & 0.31 & -0.63 & 2.71 & 11.34 & 0.26 & Navarro (1932) \\
\hline Congo & Length frequencies & 31.0 & 37.0 & 0.69 & -0.56 & 2.96 & 5.82 & 0.51 & Rossignol (1955) \\
\hline Mauritania & Scales & 34.6 & 41.6 & 0.26 & -0.87 & 2.65 & 13.11 & 0.22 & Chesheva (1998) \\
\hline Mauritania & Otoliths & 31.0 & 37.0 & 0.39 & 1.46 & 2.72 & 9.15 & 0.32 & Pascual-Alayón et al. (2008) \\
\hline Mauritania & Scales and Otoliths & 32.9 & 39.4 & 0.32 & -1.78 & 2.69 & 10.89 & 0.27 & Pascual-Alayón et al. (2008) \\
\hline Mauritania & Otoliths & 30.4 & 36.3 & 0.41 & -0.94 & 2.72 & 6.38 & 0.47 & Iglesias et al. (2009) \\
\hline Mauritania - Senegal & Scales & 34.0 & 40.7 & 0.33 & -0.60 & 2.74 & 10.81 & 0.27 & Thuoc \& Szypula (1973) \\
\hline Mauritania - Senegal & $\begin{array}{c}\text { Scales } \\
\end{array}$ & 38.1 & 45.9 & 0.36 & -0.69 & 2.87 & 9.91 & 0.30 & Maxim and Maxim (1988) \\
\hline Mauritania - Senegal & Length frequencies and Scales & 31.2 & 37.3 & 0.97 & -0.21 & 3.12 & 4.58 & 0.65 & Boëly et al.(1979) \\
\hline Senegal & Length frequencies & 35.0 & 42.0 & 0.60 & -0.24 & 3.02 & 4.75 & 0.63 & Postel (1955) \\
\hline Senegal & Scales & 35.0 & 42.1 & 0.28 & -0.99 & 2.70 & 12.22 & 0.24 & Krzeptowski (1982) \\
\hline Senegal & Length frequencies and Scales & 30.6 & 36.5 & 1.21 & -0.06 & 3.20 & 3.97 & 0.75 & Boëly et al. (1982) \\
\hline Senegal & Length frequencies & 29.4 & 35.4 & 0.26 & -0.76 & 2.51 & 10.77 & 0.27 & Present study \\
\hline
\end{tabular}


648 TABLE II: Reproductive parameters in Western Central Atlantic (i.e. Brazil and Venezuela), in Mediterranean Sea (i.e. Greece, Croatia and Tunisia) and in Eastern

649 Central Atlantic (i.e. Senegal and Mauritanian) for Sardinella aurita. TL: Total Length (cm); FL: Fork Length (cm); N: Number of individual; SR (\%): Sex Ratio;

$650 \mathrm{~L}_{50}(\mathrm{~cm})$ represents the size at which $50 \%$ of individuals in a given population reach the maturity; ' $\mathrm{a}$ ' and 'b': allometric coefficient; $(*)$ Reproduction period; NR:

651 not reported.

\begin{tabular}{|c|c|c|c|c|c|c|c|c|c|c|c|c|c|c|c|c|c|c|c|c|}
\hline \multirow{2}{*}{ Country } & \multirow{2}{*}{ Method } & \multirow{2}{*}{$\mathrm{N}$} & \multicolumn{12}{|c|}{ Month } & Male & Female & \multirow[b]{2}{*}{$\mathrm{a}$} & \multirow[b]{2}{*}{$\mathrm{b}$} & \multirow[b]{2}{*}{ SR } & \multirow[b]{2}{*}{ References } \\
\hline & & & 1 & 2 & 3 & 4 & 5 & 6 & 7 & 8 & 9 & 10 & 11 & 12 & $\mathrm{~L}_{50}$ & $\mathrm{~L}_{50}$ & & & & \\
\hline \multicolumn{21}{|c|}{ Western Central Atlantic Ocean } \\
\hline Brazil & $\mathrm{TL}$ & 250 & * & * & * & * & & & & & & & $*$ & $*$ & $\mathrm{NR}$ & 18.60 & NR & NR & NR & Petermann and Schwingel (2016) \\
\hline $\begin{array}{l}\text { Venezuela } \\
\text { Vella }\end{array}$ & TL & 92834 & * & * & * & & & & & & & & $*$ & * & NR & 19.70 & 1.0377 & 3.399 & NR & Fréon et al. (1997) \\
\hline Venezuela & TL & 3736 & * & * & * & & & & & & & * & * & $*$ & NR & 20.00 & NR & NR & 55.5 & Gassman et al. (2008) \\
\hline \multicolumn{21}{|c|}{ Mediterranean } \\
\hline Greece & $\mathrm{TL}$ & NR & & & & & * & * & * & * & & & & & 14.00 & 15.00 & NR & NR & NR & Ananiades (1952) \\
\hline Croatia & TL & 2033 & & & & & & * & * & * & & & & & 15.80 & 16.60 & NR & NR & NR & Mustać and Sinovčić (2012b) \\
\hline Greece & TL & 19 & NR & NR & NR & NR & NR & NR & NR & NR & NR & NR & NR & NR & $\mathrm{NR}$ & NR & 0.0087 & 2.950 & NR & Koutrakis and Tsikliras (2003) \\
\hline Greece & TL & 7942 & & & & & $*$ & * & & & & & & & 15.50 & 16.80 & NR & NR & 50.5 & Tsikliras and Antonopoulou (2006) \\
\hline Tunisia & TL & 918 & & & & & & & * & * & * & & & & 14.10 & 15.20 & NR & NR & $\mathrm{NR}$ & Gaamour et al. (2001) \\
\hline \multicolumn{21}{|c|}{ Eastern Central Atlantic Ocean } \\
\hline Mauritania & FL & NR & NR & NR & $\mathrm{NR}$ & NR & $\mathrm{NR}$ & NR & NR & NR & NR & NR & NR & NR & NR & $\mathrm{NR}$ & 0.007940 & 3.227 & $\mathrm{NR}$ & Lawal and Mylnikov (1988) \\
\hline Mauritania & TL & 3073 & & & & & & * & * & * & * & & & & 34.61 & 34.61 & NR & NR & 55.0 & Wague and Mbodj (2002) \\
\hline Senegal & $\mathrm{TL}$ & 1334 & & & & & * & * & & & & * & * & & NR & 23.45 & NR & NR & 52.0 & Conand (1977) \\
\hline Senegal & FL & 2232 & NR & NR & NR & NR & $\mathrm{NR}$ & $\mathrm{NR}$ & NR & NR & NR & $\mathrm{NR}$ & $\mathrm{NR}$ & $\mathrm{NR}$ & NR & NR & 0.000005 & 3.194 & NR & Boëly (1982a) \\
\hline Senegal & NR & NR & & * & * & $*$ & * & * & & & * & * & $*$ & & NR & NR & NR & NR & NR & Cury and Fontana (1988) \\
\hline Senegal & $\mathrm{TL}$ & 3947 & & & & $*$ & $*$ & $*$ & & & & $*$ & $*$ & & 27.66 & 30.98 & 0.000038 & 3.162 & 50.5 & Goudiaby et al. (2008) \\
\hline Senegal & $\mathrm{TL}$ & NR & & & & & & & & & & * & * & & 21.10 & 26.55 & 0.000007 & 3.040 & NR & Samba (2011) \\
\hline Senegal & $\mathrm{TL}$ & 4397 & & * & $*$ & $*$ & $*$ & $*$ & & & $*$ & * & * & & 24.82 & 25.72 & 0.008 & 3.02 & 51.1 & Present study \\
\hline
\end{tabular}

